\title{
JIP-test in assessing sensitivity to nitrogen deficiency in two cultivars of Actinidia arguta (Siebold et Zucc.) Planch. ex Miq.
}

\author{
T. SWOCZYNA*, B. ŁATA ${ }^{* *+}$, A. STASIAK*, J. STEFANIAK ${ }^{* *}$, and P. LATOCHA*,+ \\ Department of Environmental Protection, Faculty of Horticulture, Biotechnology, and Landscape Architecture, \\ Warsaw University of Life Sciences - SGGW, 02-776 Warsaw, Poland* \\ Laboratory of Basic Sciences in Horticulture, Faculty of Horticulture, Biotechnology, and Landscape Architecture, \\ Warsaw University of Life Sciences - SGGW, 02-776 Warsaw, Poland**
}

\begin{abstract}
Optimal nitrogen availability is necessary to keep high photosynthetic efficiency and in consequence, good physiological condition and growth of plants. In order to examine the effect of $\mathrm{N}$ nutrition on photosynthetic apparatus performance we used the chlorophyll $a$ fluorescence $(\mathrm{ChF})$ technique in two differing Actinidia cultivars and we aimed to select the most reliable $\mathrm{ChF}$ parameters showing $\mathrm{N}$ deficiency. The 4-years-old specimens growing on an experimental plantation were treated with three differing $\mathrm{N}$ doses and $\mathrm{ChF}$ data were collected during two years. The results showed that PSII performance indices, performance index on the absorption basis and total performance index, are useful to detect the overall decrease in photosynthetic apparatus vitality. Efficiency of electron movement beyond $\mathrm{Q}_{\mathrm{A}}$ into the electron transport chain was more susceptible to different $\mathrm{N}$ nutritions than maximum quantum efficiency, while a pool of $\mathrm{Q}_{\mathrm{A}}$ reducing reaction centres per PSII antenna chlorophyll, RC/ABS, and a number of $\mathrm{Q}_{\mathrm{A}}$ reducing reaction centres per cross section of a sample, $\mathrm{RC} / \mathrm{CS}_{0}$, were the best indicators of $\mathrm{N}$ deficiency.
\end{abstract}

Additional key words: fluorescence transient; kiwiberry; mini kiwi; oxygen-evolving complex; photosystem II.

\section{Introduction}

Proper nitrogen nutrition of crop plants is one of the crucial factors affecting good physiological conditions of plants, growth, and yield (Yong et al. 2010, Wang et al. 2012a). Nitrogen, being an important component of amino acids, plays the essential role in protein synthesis and in numerous biochemical processes. It is also a component of chlorophyll (Chl) so that the N-deficiency is clearly reflected by the depletion of Chl content (Chang and Robison 2003, van den Berg and Perkins 2004). Up to 50\% of total leaf $\mathrm{N}$ may be invested in the photosynthesising structures and $\mathrm{CO}_{2}$ assimilation, particularly in Rubisco (Makino 2003). Therefore, optimal $\mathrm{N}$ availability is necessary to keep a high photosynthetic efficiency (Dordas and Sioulas 2008, Wang et al. 2012a) and to enable advantageous sugar production. Moreover, the $\mathrm{N}$ availability for plants is highly connected with water availability in soil (Puri and Ashman 1998, Hu and Schmidthalter 2005). Water deficiency in soil may reduce $\mathrm{N}$ uptake despite sufficient fertilising (Teixeira et al. 2014, Bai et al. 2017), as well as
$\mathrm{N}$ accumulation in leaf tissues (Ashraf et al. 2013, da Silva et al. 2017).

Chlorophyll $a$ fluorescence $(\mathrm{ChF})$ analysis has become recently a popular research method for different purposes: from analysing photosynthetic apparatus structure to assessment of gross primary productivity (Porcar-Castell et al. 2014). This method is also used to detect environmental stress in plants, including drought stress (Percival et al. 2006, Fini et al. 2009, Wang et al. 2012b, Guo et al. 2016), thermal stress (Brestič et al. 2016), high light stress (Živčák et al. 2015b), salt stress (Mehta et al. 2010), and $\mathrm{N}$ deficiency (Kalaji et al. 2014a, 2018; Živčák et al. 2014a,b; Feng et al. 2015). There are two main methods used in examining environmental stress on living leaves. The first one is based on pulse amplitude-modulated (PAM) technique. PAM fluorimeters use a trick to separate the effect of the actinic light, which drives photosynthesis, and the low-intensity measuring light, that is used to probe the state of the photosynthetic system (Kalaji et al. 2014b). It has been used for decades to elucidate the organisation, function, and acclimation of the photosynthetic apparatus

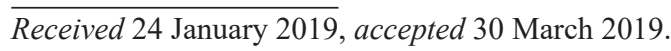

+Corresponding authors; e-mail: piotr_latocha@sggw.pl; barbara_lata@sggw.pl

Abbreviations: ABS - average photon absorption; Chl - chlorophyll; ChF - chlorophyll a fluorescence; DI - energy dissipation; ET - electron transport; ETC - electron transport chain; $F_{0}$ - minimal fluorescence yield of the dark-adapted state; $F_{m}-$ maximal fluorescence yield of the dark-adapted state; $\mathrm{F}_{\mathrm{v}} / \mathrm{F}_{\mathrm{m}}$ - maximal quantum yield of PSII photochemistry; OEC - oxygen-evolving complex; PI - performance index; RC - reaction centre; RE - reduction of end electron acceptors at the PSI acceptor side; TR - exciton trapping. Acknowledgements: This study was funded by National Centre for Research and Development (NCBiR) Poland, grant no PBS3/ A $8 / 35 / 2015$. 
at the subcellular and leaf levels. The second method is based on application of actinic light that drives photosynthesis also as a measuring light, and is performed using plant efficiency analysers (PEA). Application of light-emitting diodes (LED) of specific wavelength enables quick measurements with a high resolution (Kalaji et al. 2014b). Therefore, the latter method facilitates less timeconsuming measurements which are necessary to obtain a huge number of samples in a relatively short time (at the same light/temperature conditions) in the field experiment. In most research concerning $\mathrm{N}$ nutrition, only a couple of $\mathrm{ChF}$ parameters are applied as stress markers, such as $\mathrm{F}_{0}$, $\mathrm{F}_{\mathrm{m}}, \mathrm{F}_{\mathrm{v}} / \mathrm{F}_{\mathrm{m}}$, and sometimes additional parameters describing electron transport rate beyond PSII depending on a device used in examination protocol (e.g. Janušauskaite and Feiziene 2012, Lin et al. 2013, Feng et al. 2015). The results confirm advantageous effect of increased $\mathrm{N}$ supply on the analysed parameters, which is consistent with the general opinion on significance of $\mathrm{N}$ nutrition.

The usage of fluorimeters of high-time resolution measurements (with intervals of $10 \mu \mathrm{s}$ ) provides a dataset for plotting a fluorescence transient which, when shown on a logarithmic time scale, is called a fast (or prompt) fluorescence curve. This curve with visible points marked as $\mathrm{O}, \mathrm{J}, \mathrm{I}, \mathrm{P}$, according to Strasser and Govindjee (1992), enables to get an insight into particular phenomena concerning light absorption and its conversion to biochemical energy. Based on it, so called 'JIP-test' was developed and numerous JIP-test parameters were introduced (Strasser et al. 2000, 2004, 2010)), which describe energy fluxes occurring inside and around reaction centres (RCs) of numerous PSII localised in chloroplasts. In this way, the consecutive energy fluxes of average photon absorption (ABS), exciton trapping (TR), energy dissipation (DI), electron transport (ET), and reduction of end electron acceptors at the PSI acceptor side (RE), can be evaluated. Particularly, parameters defining quantum yields and efficiencies (or probabilities) are valuable because of their universal meaning, these are maximum quantum yield of primary photochemistry $\left(a t t_{0}\right), \mathrm{TR}_{0} / \mathrm{ABS}$ $\left(\varphi_{\mathrm{P}_{\mathrm{O}}}\right)$; probability that a trapped exciton moves an electron into the ETC beyond $\mathrm{Q}_{\mathrm{A}}, \mathrm{ET}_{0} / \mathrm{TR}_{0}\left(\psi_{\mathrm{Eo}}\right)$; and the efficiency of ET until PSI acceptors, $\mathrm{RE}_{0} / \mathrm{ET}_{0}\left(\delta_{\mathrm{Ro}}\right)$ (Strasser et al. 2004, 2010). Based on calculated specific absorption flux, $\mathrm{ABS} / \mathrm{RC}$, and experimentally accessible phenomenological absorption flux, $\mathrm{ABS} / \mathrm{CS}_{0}=\mathrm{F}_{0}$, the density of active RCs ( $\mathrm{Q}_{\mathrm{A}}$ reducing $\mathrm{RCs}$ ) per cross section at point 0 can be defined (Strasser et al. 2004). Finally, two integrative parameters, so-called performance indices, $\mathrm{PI}_{\mathrm{ABS}}$ and $\mathrm{PI}_{\text {total }}$, were introduced by Strasser et al. (2004, 2010) as multiplications of RC/ABS (a pool of active RCs per PSII antenna Chl) and particular efficiencies.

Selected JIP-test parameters and their description are listed in the following table (see the next page).

A simplified scheme presenting graphically $\mathrm{PI}_{\mathrm{ABS}}$ and $\mathrm{PI}_{\text {total }}$ calculations is shown in the Fig. 1; however, the structures involved in photochemical reactions are more complicated and differentiated. For instance, based on antenna size, PSII can be classified into three forms; $\alpha, \beta$, and $\gamma$. Likewise, on the basis of electron transport

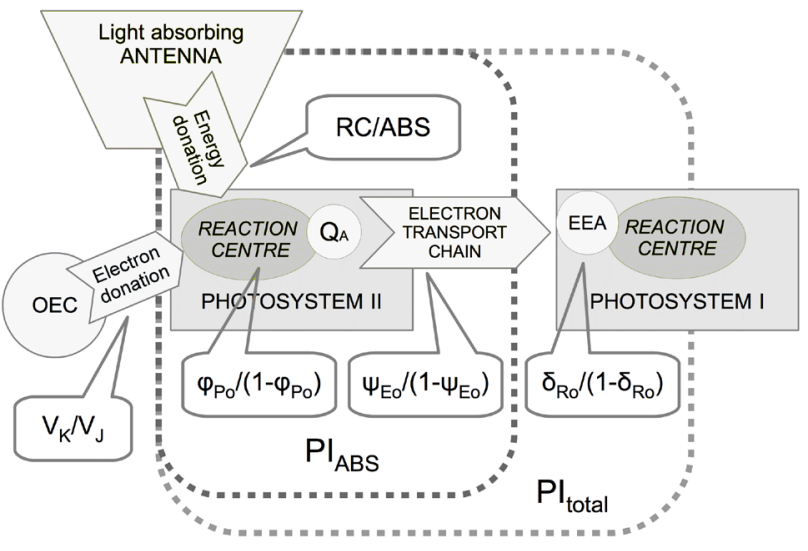

Fig. 1. A simplified scheme of $\mathrm{PI}_{\mathrm{ABS}}$ and $\mathrm{PI}_{\text {total }}$ equations. EEA end electron acceptors at photosystem I, OEC - oxygen-evolving complex (= water-splitting complex), $\mathrm{Q}_{\mathrm{A}}-$ plastoquinone A. For details see Materials and methods.

properties of the acceptor side of reaction centres, two forms of PSII were found, namely, $\mathrm{Q}_{\mathrm{B}}$ reducing centres and $\mathrm{Q}_{\mathrm{B}}$ nonreducing centres (Mehta et al. 2010). The above mentioned performance indices became useful for an assessment of stress influence on plants (Živčák et al. 2008, Swoczyna et al. 2010, Yusuf et al. 2010, Gururani et al. 2013, Kalaji et al. 2018). They enable to distinguish plant groups affected by stress (when compared to control plants) and to indicate which level of stress is vulnerable for photosynthetic machinery. Additionally, indices on basis of JIP-test can show systemic plant response to local damages, for example changes in cellular $\mathrm{pH}$ induced by environmentally affected electrical potential across the plasma membrane, i.e. variational potential (Sukhova et al. 2018). In practical operation in the field, the more unequivocal identification of stress basis is needed. Therefore, the examination of particular factors of PI multiplications seems to be more useful. RC/ABS reflects a relative number of active RCs per average antenna size (Strasser et al. 2004). This parameter is sensitive to thermal stress (Kalaji et al. 2011a, Brestič et al. 2012), drought (Strasser et al. 2010, Guha et al. 2013), and salt stress (Kalaji et al. 2011b). Elevated temperatures affect the structure of Chl-protein complexes (Allakhverdiev et al. 2008) while drought and salt-induced osmotic stress triggers partial closure of RCs (Kalaji et al. 2011b, Guha et al. 2013). The $\varphi_{\mathrm{Po}} /\left(1-\varphi_{\mathrm{Po}}\right)$ ratio, denoted also as $\mathrm{TR}_{0} / \mathrm{DI}_{0}$ or $F_{v} / F_{0}$, shows the relation between trapped energy by active RC and dissipated energy (Strasser et al. 2004). A decrease in $\varphi_{\mathrm{Po}} /\left(1-\varphi_{\mathrm{Po}}\right)$ is usually connected to drought stress (Fini et al. 2009, Swoczyna et al. 2015), heat stress (Kalaji et al. 2011a, Mathur and Jajoo 2014), or salt stress (Kalaji et al. 2011b). It should also be considered when analysing $\mathrm{N}$-deficiency becasuse $\varphi_{\mathrm{P}_{\mathrm{o}}}\left(=\mathrm{F}_{\mathrm{v}} / \mathrm{F}_{\mathrm{m}}\right)$ was reported to be sensitive to $\mathrm{N}$ nutrition (Janušauskaite and Feiziene 2012, Lin et al. 2013, Feng et al. 2015). The $\psi_{\mathrm{E}} /\left(1-\psi_{\mathrm{Eo}}\right)$ ratio concerns consecutive processes in ETC in which several molecules, such as Rieske FeS protein, cytochromes, plastocyanin, and some more, are involved. Inactivation of those structures affects linear 


\begin{tabular}{|c|c|}
\hline Fluorescence parameters & Description \\
\hline $\mathrm{F}_{0}=\mathrm{ABS} / \mathrm{CS}_{0}$ & initial fluorescence obtained from measurements, denoted also as $\mathrm{ABS} / \mathrm{CS}_{0}$ \\
\hline $\mathrm{F}_{\mathrm{K}}=\mathrm{F}_{300}$ & fluorescence at $300 \mu$ s after illumination of a dark-adapted sample \\
\hline $\mathrm{F}_{\mathrm{J}}=\mathrm{F}_{2 \mathrm{~ms}}$ & fluorescence at $2 \mathrm{~ms}$ after illumination of a dark-adapted sample \\
\hline $\mathrm{F}_{\mathrm{I}}=\mathrm{F}_{30 \mathrm{~ms}}$ & fluorescence at $30 \mathrm{~ms}$ after illumination of a dark-adapted sample \\
\hline $\mathrm{F}_{\mathrm{m}}$ & maximum fluorescence after illumination of a dark-adapted sample \\
\hline $\mathrm{V}_{\mathrm{K}}=\left(\mathrm{F}_{300}-\mathrm{F}_{0}\right) /\left(\mathrm{F}_{\mathrm{m}}-\mathrm{F}_{0}\right)$ & relative variable fluorescence at $300 \mu$ s after illumination of a dark-adapted sample \\
\hline $\mathrm{V}_{\mathrm{J}}=\left(\mathrm{F}_{2 \mathrm{~ms}}-\mathrm{F}_{0}\right) /\left(\mathrm{F}_{\mathrm{m}}-\mathrm{F}_{0}\right)$ & relative variable fluorescence at $2 \mathrm{~ms}$ after illumination of a dark-adapted sample \\
\hline $\mathrm{V}_{\mathrm{I}}=\left(\mathrm{F}_{30 \mathrm{~ms}}-\mathrm{F}_{0}\right) /\left(\mathrm{F}_{\mathrm{m}}-\mathrm{F}_{0}\right)$ & relative variable fluorescence at $30 \mathrm{~ms}$ after illumination of a dark-adapted sample \\
\hline $\mathrm{V}_{\mathrm{K}} / \mathrm{V}_{\mathrm{J}}$ & efficiency of electron flow from OEC to PSII reaction centres \\
\hline $\mathrm{M}_{0}=4\left(\mathrm{~F}_{300}-\mathrm{F}_{0}\right) /\left(\mathrm{F}_{\mathrm{m}}-\mathrm{F}_{0}\right)$ & $\begin{array}{l}\text { approximated initial slope of the fluorescence transient, expressing the rate of RCs' } \\
\text { closure }\end{array}$ \\
\hline $\mathrm{F}_{\mathrm{v}} / \mathrm{F}_{\mathrm{m}}=\varphi_{\mathrm{Po}_{\mathrm{o}}}=\mathrm{TR}_{0} / \mathrm{ABS}=\left(\mathrm{F}_{\mathrm{m}}-\mathrm{F}_{0}\right) / \mathrm{F}_{\mathrm{m}}$ & maximum quantum yield of PSII photochemistry \\
\hline$\psi_{\mathrm{o}}=\mathrm{ET}_{0} / \mathrm{TR}_{0}=\left(\mathrm{F}_{\mathrm{m}}-\mathrm{F}_{2 \mathrm{~ms}}\right) /\left(\mathrm{F}_{\mathrm{m}}-\mathrm{F}_{0}\right)=1-\mathrm{V}_{\mathrm{J}}$ & $\begin{array}{l}\text { probability that a trapped exciton moves an electron into the electron transport chain } \\
\text { beyond } \mathrm{Q}_{\mathrm{A}}\end{array}$ \\
\hline$\delta_{\mathrm{Ro}_{\mathrm{o}}}=\mathrm{RE}_{0} / \mathrm{ET}_{0}=\left(\mathrm{F}_{\mathrm{m}}-\mathrm{F}_{2 \mathrm{~ms}}\right) /\left(\mathrm{F}_{\mathrm{m}}-\mathrm{F}_{0}\right)$ & $\begin{array}{l}\text { probability that an electron from the intersystem electron carriers is transferred to } \\
\text { reduce end electron acceptors at the PSI acceptor side }\end{array}$ \\
\hline $\mathrm{RC} / \mathrm{ABS}=\gamma_{\mathrm{RC}} /\left(1-\gamma_{\mathrm{RC}}\right)=\varphi_{\mathrm{Po}_{\mathrm{o}}}\left(\mathrm{V}_{\mathrm{J}} / \mathrm{M}_{0}\right)$ & $\mathrm{Q}_{\mathrm{A}}$ reducing $\mathrm{RCs}$ per PSII antenna chlorophyll \\
\hline $\mathrm{RC} / \mathrm{CS}_{0}=\varphi_{\mathrm{Po}_{\mathrm{o}}}\left(\mathrm{V}_{\mathrm{J}} / \mathrm{M}_{0}\right)\left(\mathrm{ABS} / \mathrm{CS}_{0}\right)$ & density of active $\mathrm{RCs}\left(\mathrm{Q}_{\mathrm{A}}\right.$ reducing $\left.\mathrm{RCs}\right)$ per cross section at point 0 \\
\hline $\mathrm{PI}_{\mathrm{ABS}}=\mathrm{RC} / \mathrm{ABS} \times \varphi_{\mathrm{Po}} /\left(1-\varphi_{\mathrm{Po}}\right) \times \psi_{\mathrm{Eo}} /\left(1-\psi_{\mathrm{Eo}}\right)$ & $\begin{array}{l}\text { performance index (potential) for energy conservation from photons absorbed by } \\
\text { PSII to the reduction of intersystem electron acceptors }\end{array}$ \\
\hline $\begin{array}{l}\mathrm{PI}_{\text {total }}=\mathrm{RC} / \mathrm{ABS} \times \varphi_{\mathrm{Po}} /\left(1-\varphi_{\mathrm{Po}_{\mathrm{o}}}\right) \times \psi_{\mathrm{Eo}} /\left(1-\psi_{\mathrm{Eo}}\right) \\
\delta_{\mathrm{Ro}} /\left(1-\delta_{\mathrm{Ro}}\right)\end{array}$ & $\begin{array}{l}\text { ×performance index (potential) for energy conservation from photons absorbed by } \\
\text { PSII to the reduction of PSI end electron acceptors }\end{array}$ \\
\hline
\end{tabular}

electron transport towards PSI and, additionally, may contribute to generation of reactive oxygen species. High stress may also disturb redox processes between electron carriers, plastoquinones $\mathrm{Q}_{\mathrm{A}}$ and $\mathrm{Q}_{\mathrm{B}}$ (Mehta et al. 2010). High temperature affects also ATP-generating system (Allakhverdiev et al. 2008). Thus, a decrease in $\psi_{\mathrm{Eo}} /\left(1-\psi_{\mathrm{Eo}}\right)$ values, likewise in $\psi_{\text {Eo }}$, reflects thermal stress (Bussotti et al. 2010, Brestič et al. 2012), salt stress (Baccarin et al. 2011), or pathogen infection (Christen et al. 2007). Another ChF parameter discussed in previous research is so-called K-band. In case of drought or thermal stress, a new step arises in the fast fluorescence curve at the time of $300 \mu \mathrm{s}$, called K-step, or K-band, when only a marked shift of the fluorescence at $300 \mu \mathrm{s}$ is noted (Strasser et al. 2004, Oukarroum et al. 2007, Brestič and Živčák 2013). The appearance of $\mathrm{K}$-band is referred to restricted electron flow from OEC to the RC. This might be caused by heat inducing loss of $\mathrm{Mn}$ atoms from manganese containing clusters of OEC (Allakhverdiev et al. 2008) or by deficit of water molecules which are the source of electrons reoxidising RCs in PSII. The appearance of K-band is detected when analysing the ratio of variable fluorescence at $300 \mu \mathrm{s}$ and variable fluorescence at $2 \mathrm{~ms}\left(\mathrm{~V}_{\mathrm{K}} / \mathrm{V}_{\mathrm{J}}\right)$ (Strasser et al. 2004, Brestič and Živčák 2013). The $\mathrm{V}_{\mathrm{K}} / \mathrm{V}_{\mathrm{J}}$ ratio is not included in any PI formula; however, it might be valuable in detecting some kinds of stress.

Numerous parameters bring abundant information to specialists, but they are difficult to interpret in common practice. Thus, setting apart few particular valuable parameters detecting $\mathrm{N}$ deficiency would be very advantageous for practitioners. Actinidia arguta (Siebold \& Zucc.) Planch. ex Miq. is a dioecious vine originating from Asia and bearing very sweet aromatic fruit called kiwiberry, mini kiwi, or hardy kiwifruit, which is smaller and hairless in comparison to more popular kiwifruit (A. chinensis Planch. var. deliciosa). Kiwiberry contains more than 20 essential nutrients and a range of vitamins revealing significant benefits for human health. It is usually referred to as 'healthy fruit' or 'superfood' (Leontowicz et al. 2016, Latocha 2017). Among numerous cultivars used for commercial fruit production, 'Weiki' and 'Geneva' show differing growth characteristics. The importance of $A$. arguta as a crop plant has arisen recently but still little information regarding kiwiberry crop management, especially $\mathrm{N}$ fertilisation, can be found.

The first aim of the research was to examine the effect of $\mathrm{N}$ nutrition on two differing Actinidia cultivars, 'Weiki' and 'Geneva'. We hypothesised that, as the both cultivars differ in growth characteristics, they would also differ in light energy management facing nitrogen deficiency. The second objective was to select the most reliable $\mathrm{ChF}$ parameters showing $\mathrm{N}$ deficiency in Actinidia, an example of a perennial crop vine. It was hypothesised plants deficient in nitrogen would have primarily decreased the parameters concerning $\mathrm{Chl}$ molecules performance because $\mathrm{N}$ deficiency is often reflected by the depletion of Chl content.

\section{Materials and methods}

Plant material and experiment design: The experiment was conducted in mature kiwiberry orchard in Bodzew, Mazowieckie State, Poland (51'47'49.9"N, 2048'44.0"E) in the years 2015-2016. Plants were planted in 2011 with $7: 1$ female to male ratio. Specimens were set out in rows with $4 \times 4 \mathrm{~m}$ spacing. A. arguta is a climbing plant; the 
plants were supported by a T-bar construction connected by five carrying wires ( $2 \mathrm{~m}$ high and $2 \mathrm{~m}$ wide). Plots for two cultivars ('Geneva' and 'Weiki') with three N treatments; low (LN), standard (SN), and high $\mathrm{N}$ supply (HN) [3, 5, and $8 \mathrm{mg}(\mathrm{N}) 100 \mathrm{~g}^{-1}$ (soil DM), respectively], and three repetitions (i.e. blocks, each encompassing four specimens) were randomly selected. Fertilisation was conducted with three equal doses (at amounts dependent on $\mathrm{N}$ treatment) of ammonium nitrate $(34 \% \mathrm{~N})$ at the beginning of April, end of May, and end of June. The weather data (precipitation and temperature) were collected during whole experiment using Vantage Pro2 Plus weather station (Davis, USA).

Chl $\boldsymbol{a}$ fluorescence measurements: ChF was measured five times per year with 3-week interval starting from the beginning of June each year. Fast kinetics of ChF was measured using a HandyPEA fluorimeter (Hansatech Instruments Ltd., King's Lynn, Norfolk, Great Britain). Ten leaves from terminating shoots per each block were collected. It was taken into account to obtain the leaves from the plants of the same height, being of similar size, and representing the typical appearance for particular $\mathrm{N}$ treatment. They were immediately put in paper bags and transported to shaded service area at the edge of the plantation. Then the leaves were dark-adapted using lightexcluding clips for minimum $20 \mathrm{~min}$. The dark-adapted leaf samples of 4-mm diameter within each clip were illuminated with 660 -nm light of 3,444 $\mu \mathrm{mol}$ (photon) $\mathrm{m}^{-2} \mathrm{~s}^{-1}$.

Based on $\mathrm{ChF}$ measurements, the following parameters of the JIP-test were calculated: density of active RCs $\left(\mathrm{Q}_{\mathrm{A}}\right.$ reducing $\left.\mathrm{RCs}\right)$ per cross section at point $0, \mathrm{RC} / \mathrm{CS}_{0}$; quantum yields and efficiencies, $\mathrm{V}_{\mathrm{K}} / \mathrm{V}_{\mathrm{J}}, \varphi_{P_{\mathrm{o}}}\left(=\mathrm{F}_{\mathrm{v}} / \mathrm{F}_{\mathrm{m}}\right)$, $\psi_{\mathrm{Eo}}, \delta_{\mathrm{Ro}}$; and performance indices, $\mathrm{PI}_{\mathrm{ABS}}$ and $\mathrm{PI}_{\text {total }}$. In order to assess which factors of $\mathrm{PI}_{\mathrm{ABS}}$ and $\mathrm{PI}_{\text {total }}$ equations were determined by different $\mathrm{N}$ supply, the consecutive mathematical factors, RC/ABS, $\varphi_{\mathrm{Po}} /\left(1-\varphi_{\mathrm{Po}}\right), \psi_{\mathrm{Eo}} /\left(1-\psi_{\mathrm{Eo}}\right)$, and $\delta_{\mathrm{Ro}} /\left(1-\delta_{\mathrm{Ro}}\right)$, were analysed.

Chl and leaf $\mathbf{N}$ content: Along with Chl $a$ fluorescence measurements, total $\mathrm{N}$ concentration in leaves of the same plants was determined using the standard Kjeldahl method and expressed as percentage of dry mass. The analyses were carried out in the Regional Laboratory of a Chemical and Agricultural Station in Warsaw, Żółkiewskiego Str. 17, accredited by the Polish Centre for Accreditation. Relative $\mathrm{Chl}$ content was measured on the leaves collected for $\mathrm{ChF}$ measurements using CL-01, a dual-wavelength (620 and $940 \mathrm{~nm}$ ) optical Chl content meter (Hansatech Instruments Ltd, King's Lynn, Norfolk, Great Britain).

Statistical analysis: Two-way analysis of variance (ANOVA) was performed on summarised data from each season in order to compare the effect of $\mathrm{N}$ treatment and cultivar traits. As in most comparisons, interactions between cultivar traits and $\mathrm{N}$ treatment were found, in order to compare the differences between N-supply in each cultivar and at each date, a one-way ANOVA was used with the significance of differences being determined by the Tukey's post-hoc test at the significant level of $P_{0.05}$. A principal component analysis (PCA) was performed on a correlation matrix of three means from $\mathrm{LN}, \mathrm{SN}$, and $\mathrm{HN}$ treatment and of all measurement days in each year. All calculations were made using STATISTICA version 13.0 software (TIBCO Software Inc. (2017), http://statistica.io., USA).

\section{Results}

Despite abundant precipitation in April 2015, the next months of the growing season were much drier compared to data from long-term average precipitation records in May, June, and July. The total precipitation in 2015 was $425.4 \mathrm{~mm}$, which was only $80 \%$ of the total long-term records. The precipitation in May and June 2016 was lower again, however, in July and August it exceeded the longterm monthly means (Fig. $2 A$ ). The average temperature in both seasons (2015 and 2016) was higher than longterm average $\left(9.9\right.$ and $9.2^{\circ} \mathrm{C}$, respectively, vs. $\left.7.6^{\circ} \mathrm{C}\right)$. The first part of the 2015 season (March-June) was much warmer and the second part (July-September) was colder in comparison to the long-term average. In turn, the year 2016 revealed a similar temperature distribution compared to the long-term average, but at a slightly higher level (Fig 2B).

Two Actinidia arguta cultivars showed different reactions both to $\mathrm{N}$ nutrition and to climatic conditions. In dry June 2015, the maximum quantum efficiency $\left(F_{v} / F_{m}\right)$ was strongly affected in 'Geneva' showing values not exceeding 0.8 . In 'Weiki', low $\mathrm{F}_{\mathrm{v}} / \mathrm{F}_{\mathrm{m}}$ was noted only in July (Fig. 3A). In 2016, both cultivars showed high $\mathrm{F}_{\mathrm{v}} / \mathrm{F}_{\mathrm{m}}$ in June and July and a depletion of this parameter in August, however, 'Weiki' revealed higher maximum quantum efficiency during the whole season compared to 'Geneva' (Fig. $3 B$ ), showing no interaction with $\mathrm{N}$ treatment (except from most other parameters). Different $\mathrm{N}$ treatment did not affect $F_{\mathrm{v}} / F_{\mathrm{m}}\left(\varphi_{\mathrm{Po}}\right)$ in 2015 in 'Weiki', except June 24, and in 'Geneva', except August 6, which was also reflected by $\varphi_{\mathrm{Po}} /\left(1-\varphi_{\mathrm{Po}}\right)($ Table 1$)$.

The efficiency of total electron transport beyond $\mathrm{Q}_{\mathrm{A}}$ $\left(\psi_{\mathrm{EO}}\right)$ showed significant differences between $\mathrm{N}$ treatments in early growing season 2015 ('Weiki') or late growing season 2015 ('Geneva'), and during the whole growing season 2016 (both 'Weiki' and 'Geneva') (Fig. 3C,D). The same was reflected by mathematically transferred $\psi_{\text {Eo }} /\left(1-\psi_{\text {Eo }}\right)($ Tables 1,2$)$. Two-way ANOVA indicated the significant effect of $\mathrm{N}$ nutrition, as well as of cultivar traits in each season, in every comparison, but no interaction between N nutrition and cultivar traits in 2015 and 2016.

In 2015, the efficiency of total electron transport up to end electron acceptors of PSI $\left(\delta_{\text {Ro }}\right)$ revealed similar pattern in all treatments in both cultivars except June 24, when 'Weiki' showed lower $\delta_{\text {Ro }}$ in LN, and August 6 and 27, when in LN 'Geneva' the $\delta_{\text {Ro }}$ value was the highest. The significance of differences in $\delta_{\text {Ro }}$ followed the differences in $\delta_{\mathrm{Ro}} /\left(1-\delta_{\mathrm{Ro}}\right)$ ratio (Table 1$)$. Likewise, in 2016, 'Weiki' had lower $\delta_{\text {Ro }}$ in LN on 23 June, and 'Geneva' revealed higher $\delta_{\text {Ro }}$ in LN at particular measurement days (data not shown, see $\delta_{\mathrm{Ro}} /\left(1-\delta_{\mathrm{Ro}}\right)$ ratio in Table 2$)$.

Increased $\mathrm{N}$ doses affected positively both performance indices in 2015, however, the two cultivars showed 


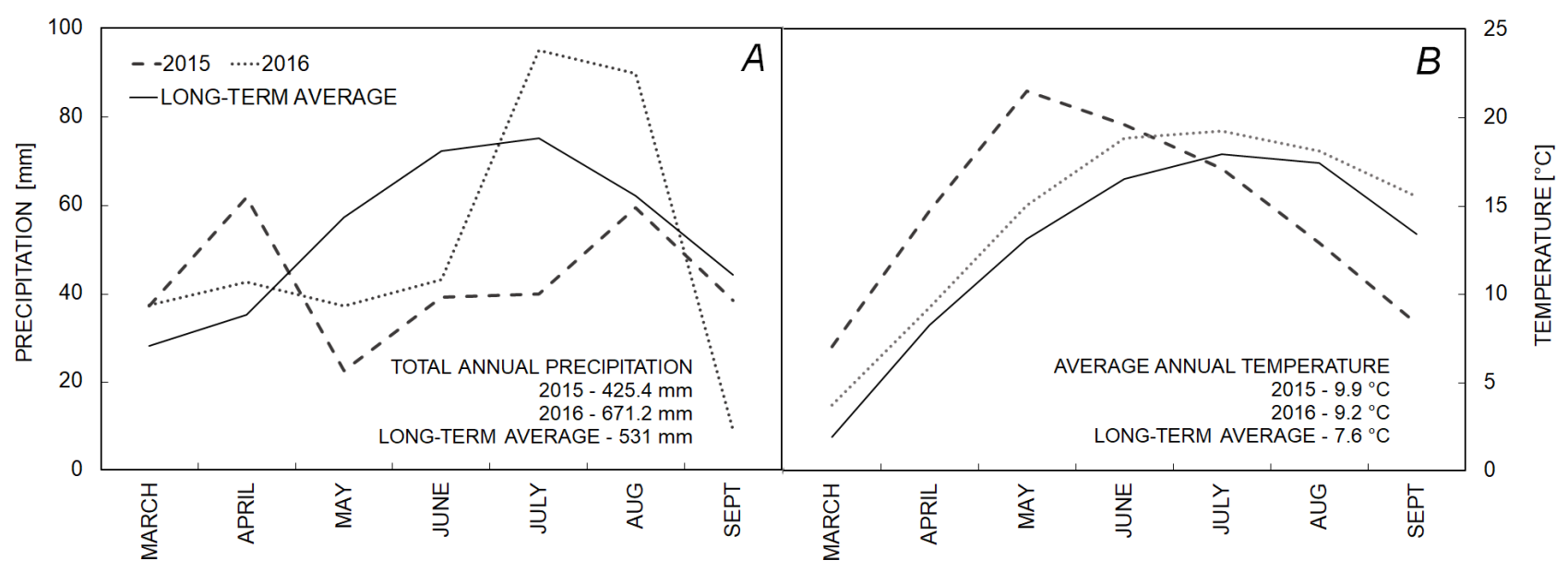

Fig. 2. Mean monthly precipitation $(A)$ and temperature $(B)$ in 2015 and 2016, and the long-term average monthly precipitation and temperature, respectively.

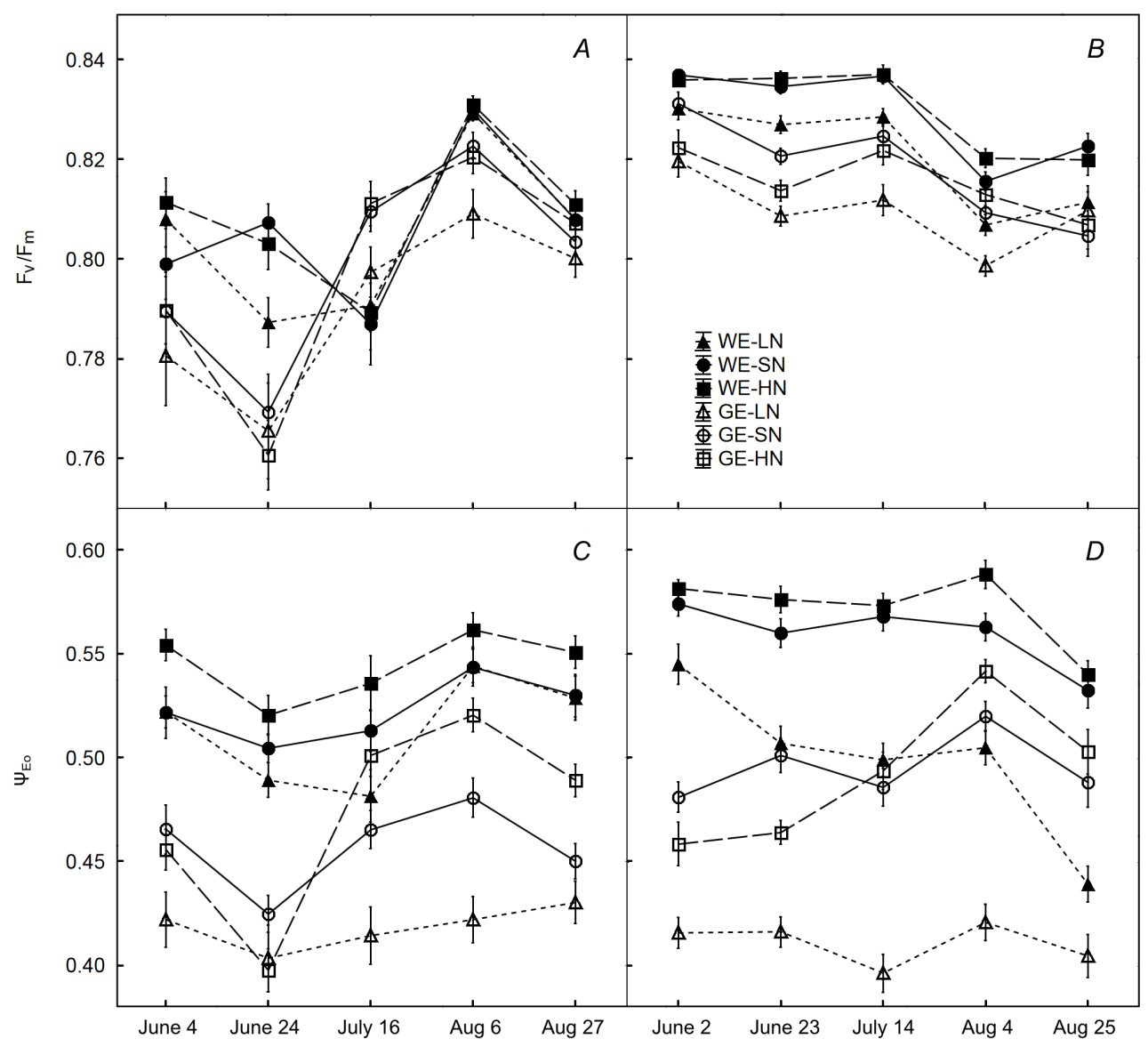

Fig. 3. Maximum quantum efficiency $\left(\mathrm{F}_{\mathrm{v}} / \mathrm{F}_{\mathrm{m}}=\varphi_{\mathrm{P}_{\mathrm{o}}}\right)$ during the growing seasons $2015(A)$ and $2016(B)$ and efficiency of total electron transport beyond $\mathrm{Q}_{\mathrm{A}}\left(\psi_{\mathrm{F}_{\mathrm{O}}}\right)$ during the growing seasons $2015(C)$ and $2016(D)$ in two Actinidia arguta cultivars 'Weiki' (WE) and 'Geneva' (GE). The plants were treated with minimal (LN), standard (SN), and increased (HN) nitrogen supply. Values are means $\pm \mathrm{SE}$.

different reactions. 'Weiki' was significantly affected in the early growing season, while 'Geneva' in July and August (Table 1). In 2016, both cultivars revealed significant differences at all measurement days. In 'Weiki', the higher $\mathrm{N}$ doses were applied, the higher $\mathrm{PI}_{\mathrm{ABS}}$ and $\mathrm{PI}_{\text {total }}$ values were noted. In 'Geneva', the highest $\mathrm{PI}_{\mathrm{ABS}}$ and $\mathrm{PI}_{\text {total }}$ were obtained at standard $\mathrm{N}$ doses (Table 2). Dry June 2015 contributed to depletion of $\mathrm{PI}_{\mathrm{ABS}}$ in both cultivars, 
Table 1. Chlorophyll $a$ fluorescence parameters in 'Weiki' and 'Geneva' in 2015. For each parameter, small superscript letters indicate statistically homogenous groups (ANOVA, Tukey's HSD test, $P \leq 0.05$ ). LN, SN, HN -3 , 5 , and $8 \mathrm{mg}(\mathrm{N}) 100 \mathrm{~g}^{-1}$ (soil $\left.\mathrm{DM}\right)$, respectively.

\begin{tabular}{|c|c|c|c|c|c|c|c|}
\hline Cultivar & Parameter & $\mathrm{N}$ treatment & June 4 & June 24 & July 16 & August 6 & August 27 \\
\hline \multirow[t]{24}{*}{ Weiki } & \multirow[t]{3}{*}{$\mathrm{V}_{\mathrm{K}} / \mathrm{V}_{\mathrm{J}}$} & $\mathrm{LN}$ & 0.385 & $0.386^{\mathrm{b}}$ & 0.403 & 0.360 & 0.353 \\
\hline & & SN & 0.390 & $0.352^{\mathrm{a}}$ & 0.370 & 0.359 & 0.354 \\
\hline & & $\mathrm{HN}$ & 0.377 & $0.353^{\mathrm{a}}$ & 0.374 & 0.350 & 0.341 \\
\hline & \multirow[t]{3}{*}{$\mathrm{RC} / \mathrm{CS}_{0}$} & $\mathrm{LN}$ & 380.5 & $404.7^{\mathrm{a}}$ & $380.4^{\mathrm{a}}$ & $406.1^{\mathrm{a}}$ & $427.6^{\mathrm{a}}$ \\
\hline & & SN & 375.8 & $443.3^{\mathrm{b}}$ & $411.1^{\mathrm{b}}$ & $411.2^{\mathrm{ab}}$ & $432.4^{\mathrm{ab}}$ \\
\hline & & $\mathrm{HN}$ & 391.6 & $442.9^{b}$ & $414.1^{\mathrm{b}}$ & $429.6^{\mathrm{b}}$ & $451.1^{\mathrm{b}}$ \\
\hline & \multirow[t]{3}{*}{$\mathrm{RC} / \mathrm{ABS}$} & $\mathrm{LN}$ & 0.636 & $0.618^{\mathrm{a}}$ & 0.594 & 0.698 & 0.694 \\
\hline & & SN & 0.619 & $0.690^{\mathrm{b}}$ & 0.642 & 0.700 & 0.693 \\
\hline & & $\mathrm{HN}$ & 0.653 & $0.686^{\mathrm{b}}$ & 0.647 & 0.716 & 0.716 \\
\hline & \multirow[t]{3}{*}{$\varphi_{\mathrm{Po}} /\left(1-\varphi_{\mathrm{Po}}\right)$} & $\mathrm{LN}$ & 4.278 & $3.747^{\mathrm{a}}$ & 3.833 & 4.867 & 4.268 \\
\hline & & $\mathrm{SN}$ & 4.069 & $4.223^{\mathrm{b}}$ & 3.793 & 4.902 & 4.248 \\
\hline & & $\mathrm{HN}$ & 4.363 & $4.138^{\mathrm{ab}}$ & 3.837 & 4.935 & 4.323 \\
\hline & \multirow[t]{3}{*}{$\psi_{\mathrm{EO}} /\left(1-\psi_{\mathrm{EO}}\right)$} & $\mathrm{LN}$ & $1.101^{\mathrm{a}}$ & $0.967^{\mathrm{a}}$ & $0.948^{\mathrm{a}}$ & 1.216 & 1.152 \\
\hline & & SN & $1.112^{\mathrm{a}}$ & $1.025^{\mathrm{ab}}$ & $1.069^{\mathrm{ab}}$ & 1.217 & 1.158 \\
\hline & & $\mathrm{HN}$ & $1.255^{\mathrm{b}}$ & $1.100^{\mathrm{b}}$ & $1.182^{\mathrm{b}}$ & 1.304 & 1.246 \\
\hline & \multirow[t]{3}{*}{$\mathrm{PI}_{\mathrm{ABS}}$} & $\mathrm{LN}$ & 3.089 & $2.297^{\mathrm{a}}$ & 2.248 & 4.231 & 3.580 \\
\hline & & SN & 2.896 & $3.035^{\mathrm{b}}$ & 2.719 & 4.303 & 3.573 \\
\hline & & $\mathrm{HN}$ & 3.648 & $3.217^{\mathrm{b}}$ & 3.104 & 4.706 & 3.959 \\
\hline & \multirow[t]{3}{*}{$\delta_{\mathrm{Ro}} /\left(1-\delta_{\mathrm{Ro}}\right)$} & $\mathrm{LN}$ & 0.844 & $0.717^{\mathrm{a}}$ & 0.593 & 0.561 & 0.572 \\
\hline & & $\mathrm{SN}$ & 0.887 & $0.823^{\mathrm{b}}$ & 0.560 & 0.534 & 0.548 \\
\hline & & $\mathrm{HN}$ & 0.918 & $0.832^{\mathrm{b}}$ & 0.579 & 0.509 & 0.562 \\
\hline & \multirow[t]{3}{*}{$P I_{\text {total }}$} & $\mathrm{LN}$ & $2.555^{\mathrm{a}}$ & $1.655^{\mathrm{a}}$ & 1.342 & 2.369 & 2.059 \\
\hline & & $\mathrm{SN}$ & $2.590^{\mathrm{ab}}$ & $2.519^{\mathrm{b}}$ & 1.588 & 2.317 & 1.998 \\
\hline & & $\mathrm{HN}$ & $3.314^{\mathrm{b}}$ & $2.654^{\mathrm{b}}$ & 1.898 & 2.407 & 2.226 \\
\hline \multirow[t]{24}{*}{ Geneva } & \multirow[t]{3}{*}{$\mathrm{V}_{\mathrm{K}} / \mathrm{V}_{\mathrm{J}}$} & $\mathrm{LN}$ & $0.514^{b}$ & 0.472 & $0.516^{\mathrm{b}}$ & $0.520^{\mathrm{c}}$ & $0.468^{\mathrm{b}}$ \\
\hline & & SN & $0.468^{\mathrm{a}}$ & 0.442 & $0.444^{\mathrm{a}}$ & $0.452^{\mathrm{b}}$ & $0.438^{\mathrm{ab}}$ \\
\hline & & $\mathrm{HN}$ & $0.471^{\mathrm{a}}$ & 0.475 & $0.427^{\mathrm{a}}$ & $0.410^{\mathrm{a}}$ & $0.409^{\mathrm{a}}$ \\
\hline & \multirow[t]{3}{*}{$\mathrm{RC} / \mathrm{CS}_{0}$} & $\mathrm{LN}$ & $304.0^{\mathrm{a}}$ & 362.0 & $321.7^{\mathrm{a}}$ & $307.0^{\mathrm{a}}$ & $330.2^{\mathrm{a}}$ \\
\hline & & SN & $340.5^{\mathrm{b}}$ & 384.9 & $374.2^{\mathrm{b}}$ & $360.8^{\mathrm{b}}$ & $360.2^{\mathrm{b}}$ \\
\hline & & $\mathrm{HN}$ & $337.0^{\mathrm{b}}$ & 366.7 & $391.1^{\mathrm{b}}$ & $394.3^{c}$ & $394.7^{c}$ \\
\hline & \multirow[t]{3}{*}{$\mathrm{RC} / \mathrm{ABS}$} & LN & $0.459^{\mathrm{a}}$ & 0.497 & $0.471^{\mathrm{a}}$ & $0.479^{\mathrm{a}}$ & $0.524^{\mathrm{a}}$ \\
\hline & & SN & $0.509^{\mathrm{b}}$ & 0.525 & $0.552^{\mathrm{b}}$ & $0.552^{\mathrm{b}}$ & $0.559^{\mathrm{ab}}$ \\
\hline & & $\mathrm{HN}$ & $0.507^{b}$ & 0.485 & $0.575^{\mathrm{b}}$ & $0.607^{c}$ & $0.599^{\mathrm{b}}$ \\
\hline & \multirow[t]{3}{*}{$\varphi_{\mathrm{PO}_{\mathrm{O}}} /\left(1-\varphi_{\mathrm{Po}}\right)$} & $\mathrm{LN}$ & $3.710 \mathrm{~b}$ & 3.374 & 3.991 & $4.322^{\mathrm{a}}$ & 4.051 \\
\hline & & SN & 3.853 & 3.408 & 4.288 & $4.618^{\mathrm{ab}}$ & 4.117 \\
\hline & & $\mathrm{HN}$ & 3.845 & 3.238 & 4.345 & $4.678^{\mathrm{b}}$ & 4.229 \\
\hline & \multirow[t]{3}{*}{$\psi_{\mathrm{EO}} /\left(1-\psi_{\mathrm{Eo}}\right)$} & LN & $0.746^{\mathrm{a}}$ & 0.698 & 0.698 & $0.750^{\mathrm{a}}$ & $0.772^{\mathrm{a}}$ \\
\hline & & SN & $0.885^{\mathrm{b}}$ & 0.745 & 0.745 & $0.945^{\mathrm{b}}$ & $0.831^{\mathrm{a}}$ \\
\hline & & $\mathrm{HN}$ & $0.848^{\mathrm{ab}}$ & 0.668 & 0.668 & $1.103^{\mathrm{c}}$ & $0.970^{\mathrm{b}}$ \\
\hline & \multirow[t]{3}{*}{$\mathrm{PI}_{\mathrm{ABS}}$} & $\mathrm{LN}$ & 1.375 & 1.294 & $1.451^{\mathrm{a}}$ & $1.685^{\mathrm{a}}$ & $1.739^{\mathrm{a}}$ \\
\hline & & SN & 1.815 & 1.382 & $2.156^{\mathrm{b}}$ & $2.530^{\mathrm{b}}$ & $1.984^{\mathrm{a}}$ \\
\hline & & $\mathrm{HN}$ & 1.735 & 1.096 & $2.628^{\mathrm{b}}$ & $3.202^{\mathrm{c}}$ & $2.535^{\mathrm{b}}$ \\
\hline & \multirow[t]{3}{*}{$\delta_{\mathrm{Ro}} /\left(1-\delta_{\mathrm{Ro}}\right)$} & $\mathrm{LN}$ & 0.847 & 0.728 & 0.606 & $0.663^{\mathrm{b}}$ & $0.655^{\mathrm{b}}$ \\
\hline & & SN & 0.802 & 0.723 & 0.548 & $0.551^{\text {ba }}$ & $0.604^{\mathrm{ab}}$ \\
\hline & & $\mathrm{HN}$ & 0.835 & 0.736 & 0.561 & $0.570^{\mathrm{a}}$ & $0.558^{\mathrm{a}}$ \\
\hline & \multirow[t]{3}{*}{$\mathrm{PI}_{\text {total }}$} & $\mathrm{LN}$ & 1.093 & 0.921 & $0.848^{\mathrm{a}}$ & $1.041^{\mathrm{a}}$ & $1.074^{\mathrm{a}}$ \\
\hline & & $\mathrm{SN}$ & 1.409 & 0.981 & $1.156^{\mathrm{ab}}$ & $1.357^{\mathrm{ab}}$ & $1.149^{\mathrm{ab}}$ \\
\hline & & $\mathrm{HN}$ & 1.408 & 0.797 & $1.394^{\mathrm{b}}$ & $1.774^{\mathrm{c}}$ & $1.369^{\mathrm{b}}$ \\
\hline
\end{tabular}


Table 2. Chlorophyll $a$ fluorescence parameters in 'Weiki' and 'Geneva' in 2016. For each parameter, small superscript letters indicate statistically homogenous groups (ANOVA, Tukey's HSD test, $P \leq 0.05$ ). LN, $\mathrm{SN}, \mathrm{HN}-3,5$, and $8 \mathrm{mg}(\mathrm{N}) 100 \mathrm{~g}^{-1}$ (soil DM), respectively.

\begin{tabular}{|c|c|c|c|c|c|c|c|}
\hline Cultivar & Parameter & $\mathrm{N}$ treatment & June 2 & June 23 & July 14 & August 4 & August 25 \\
\hline \multirow[t]{24}{*}{ Weiki } & \multirow[t]{3}{*}{$\mathrm{V}_{\mathrm{K}} / \mathrm{V}_{\mathrm{J}}$} & $\mathrm{LN}$ & $0.399^{\mathrm{b}}$ & $0.386^{\mathrm{b}}$ & $0.382^{\mathrm{b}}$ & $0.433^{\mathrm{b}}$ & $0.440^{\mathrm{b}}$ \\
\hline & & $\mathrm{SN}$ & $0.367^{\mathrm{a}}$ & $0.350^{\mathrm{a}}$ & $0.336^{\mathrm{a}}$ & $0.367^{\mathrm{a}}$ & $0.346^{\mathrm{a}}$ \\
\hline & & $\mathrm{HN}$ & $0.370^{\mathrm{a}}$ & $0.338^{\mathrm{a}}$ & $0.339^{\mathrm{a}}$ & $0.355^{\mathrm{a}}$ & $0.348^{\mathrm{a}}$ \\
\hline & \multirow[t]{3}{*}{$\mathrm{RC} / \mathrm{CS}_{0}$} & $\mathrm{LN}$ & $384.6^{\mathrm{a}}$ & $366.2^{\mathrm{a}}$ & $373.5^{\mathrm{a}}$ & $333.4^{\mathrm{a}}$ & $329.3^{\mathrm{a}}$ \\
\hline & & SN & $414.7^{\mathrm{b}}$ & $406.9^{b}$ & $428.8^{\mathrm{b}}$ & $392.3^{\mathrm{b}}$ & $433.5^{\mathrm{b}}$ \\
\hline & & $\mathrm{HN}$ & $414.4^{b}$ & $416.0^{\mathrm{b}}$ & $430.1^{\mathrm{b}}$ & $410.0^{\mathrm{b}}$ & $438.9^{b}$ \\
\hline & \multirow[t]{3}{*}{$\mathrm{RC} / \mathrm{ABS}$} & $\mathrm{LN}$ & $0.633^{\mathrm{a}}$ & $0.650^{\mathrm{a}}$ & $0.650^{\mathrm{a}}$ & $0.569^{\mathrm{a}}$ & $0.562^{\mathrm{a}}$ \\
\hline & & $\mathrm{SN}$ & $0.687^{b}$ & $0.719^{b}$ & $0.719^{b}$ & $0.670^{\mathrm{b}}$ & $0.717^{\mathrm{b}}$ \\
\hline & & $\mathrm{HN}$ & $0.680^{\mathrm{b}}$ & $0.745^{\mathrm{b}}$ & $0.745^{\mathrm{b}}$ & $0.696^{\mathrm{b}}$ & $0.711^{\mathrm{b}}$ \\
\hline & \multirow[t]{3}{*}{$\varphi_{\mathrm{Po}} /\left(1-\varphi_{\mathrm{Po}}\right)$} & $\mathrm{LN}$ & $4.903^{\mathrm{a}}$ & $4.790^{\mathrm{a}}$ & $4.840^{\mathrm{a}}$ & $4.190^{\mathrm{a}}$ & $4.344^{\mathrm{a}}$ \\
\hline & & SN & $5.127^{\mathrm{b}}$ & $5.053^{\mathrm{b}}$ & $5.122^{b}$ & $4.434^{b}$ & $4.664^{b}$ \\
\hline & & $\mathrm{HN}$ & $5.094^{\mathrm{b}}$ & $5.110^{\mathrm{b}}$ & $5.147^{\mathrm{b}}$ & $4.573^{\mathrm{b}}$ & $4.589^{\mathrm{ab}}$ \\
\hline & \multirow[t]{3}{*}{$\psi_{\mathrm{Eo}} /\left(1-\psi_{\mathrm{EO}}\right)$} & $\mathrm{LN}$ & $1.226^{\mathrm{a}}$ & $1.047^{\mathrm{a}}$ & $1.012^{\mathrm{a}}$ & $1.037^{\mathrm{a}}$ & $0.797^{\mathrm{a}}$ \\
\hline & & $\mathrm{SN}$ & $1.362^{\mathrm{b}}$ & $1.289^{\mathrm{b}}$ & $1.332^{\mathrm{b}}$ & $1.304^{\mathrm{b}}$ & $1.161^{\mathrm{b}}$ \\
\hline & & $\mathrm{HN}$ & $1.397^{\mathrm{b}}$ & $1.376^{\mathrm{b}}$ & $1.357^{\mathrm{b}}$ & $1.449^{\mathrm{c}}$ & $1.189^{b}$ \\
\hline & \multirow[t]{3}{*}{$\mathrm{PI}_{\mathrm{ABS}}$} & $\mathrm{LN}$ & $3.954^{\mathrm{a}}$ & $3.373^{\mathrm{a}}$ & $3.319^{\mathrm{a}}$ & $2.541^{\mathrm{a}}$ & $2.041^{\mathrm{a}}$ \\
\hline & & SN & $4.847^{\mathrm{b}}$ & $4.776^{\mathrm{b}}$ & $5.228^{\mathrm{b}}$ & $3.937^{\mathrm{b}}$ & $4.018^{\mathrm{b}}$ \\
\hline & & $\mathrm{HN}$ & $4.870^{\mathrm{b}}$ & $5.301^{\mathrm{b}}$ & $5.277^{\mathrm{b}}$ & $4.705^{\mathrm{c}}$ & $3.985^{\mathrm{b}}$ \\
\hline & \multirow[t]{3}{*}{$\delta_{\mathrm{Ro}} /\left(1-\delta_{\mathrm{Ro}}\right)$} & LN & 0.800 & $0.612^{\mathrm{a}}$ & 0.606 & 0.589 & 0.600 \\
\hline & & $\mathrm{SN}$ & 0.800 & $0.633^{\mathrm{ab}}$ & 0.610 & 0.617 & 0.564 \\
\hline & & $\mathrm{HN}$ & 0.806 & $0.658^{\mathrm{b}}$ & 0.622 & 0.620 & 0.551 \\
\hline & \multirow[t]{3}{*}{$\mathrm{PI}_{\text {total }}$} & $\mathrm{LN}$ & $3.115^{\mathrm{a}}$ & $2.091^{\mathrm{a}}$ & $2.006^{\mathrm{a}}$ & $1.503^{\mathrm{a}}$ & $1.232^{\mathrm{a}}$ \\
\hline & & SN & $3.882^{\mathrm{b}}$ & $3.055^{\mathrm{b}}$ & $3.224^{\mathrm{b}}$ & $2.408^{\mathrm{b}}$ & $2.307^{\mathrm{b}}$ \\
\hline & & $\mathrm{HN}$ & $3.944^{b}$ & $3.530^{\mathrm{b}}$ & $3.308^{b}$ & $2.907^{\mathrm{c}}$ & $2.260^{\mathrm{b}}$ \\
\hline \multirow[t]{24}{*}{ Geneva } & \multirow[t]{3}{*}{$\mathrm{V}_{\mathrm{K}} / \mathrm{V}_{\mathrm{J}}$} & $\mathrm{LN}$ & $0.505^{\mathrm{b}}$ & $0.483^{\mathrm{b}}$ & $0.491^{\mathrm{b}}$ & $0.520^{\mathrm{b}}$ & $0.517^{\mathrm{b}}$ \\
\hline & & $\mathrm{SN}$ & $0.438^{\mathrm{a}}$ & $0.409^{\mathrm{a}}$ & $0.394^{\mathrm{a}}$ & $0.403^{\mathrm{a}}$ & $0.404^{\mathrm{a}}$ \\
\hline & & $\mathrm{HN}$ & $0.459^{\mathrm{a}}$ & $0.436^{\mathrm{a}}$ & $0.392^{\mathrm{a}}$ & $0.398^{\mathrm{a}}$ & $0.387^{\mathrm{a}}$ \\
\hline & \multirow[t]{3}{*}{$\mathrm{RC} / \mathrm{CS}_{0}$} & $\mathrm{LN}$ & $308.8^{\mathrm{a}}$ & $319.6^{\mathrm{a}}$ & $322.5^{\mathrm{a}}$ & $296.5^{\mathrm{a}}$ & $289.7^{\mathrm{a}}$ \\
\hline & & SN & $371.9^{b}$ & $377.8^{\mathrm{b}}$ & $401.0^{\mathrm{b}}$ & $392.4^{\mathrm{b}}$ & $408.9^{b}$ \\
\hline & & $\mathrm{HN}$ & $371.0^{\mathrm{b}}$ & $360.4^{b}$ & $401.9^{\mathrm{b}}$ & $387.4^{\mathrm{b}}$ & $409.9^{b}$ \\
\hline & \multirow[t]{3}{*}{$\mathrm{RC} / \mathrm{ABS}$} & $\mathrm{LN}$ & $0.491^{\mathrm{a}}$ & $0.508^{\mathrm{a}}$ & $0.504^{\mathrm{a}}$ & $0.469^{\mathrm{a}}$ & $0.479^{\mathrm{a}}$ \\
\hline & & $\mathrm{SN}$ & $0.575^{\mathrm{b}}$ & $0.608^{\mathrm{c}}$ & $0.635^{\mathrm{b}}$ & $0.607^{\mathrm{b}}$ & $0.604^{b}$ \\
\hline & & $\mathrm{HN}$ & $0.543^{\mathrm{b}}$ & $0.564^{b}$ & $0.636^{\mathrm{b}}$ & $0.614^{b}$ & $0.633^{\mathrm{b}}$ \\
\hline & \multirow[t]{3}{*}{$\varphi_{\mathrm{Po}} /\left(1-\varphi_{\mathrm{Po}}\right)$} & $\mathrm{LN}$ & $4.575^{\mathrm{a}}$ & $4.236^{\mathrm{a}}$ & $4.349^{\mathrm{a}}$ & $3.977^{\mathrm{a}}$ & 4.305 \\
\hline & & $\mathrm{SN}$ & $4.941^{\mathrm{b}}$ & $4.581^{\mathrm{b}}$ & $4.717^{\mathrm{b}}$ & $4.261^{\mathrm{b}}$ & 4.172 \\
\hline & & $\mathrm{HN}$ & $4.681^{\mathrm{ab}}$ & $4.380^{\mathrm{a}}$ & $4.641^{\mathrm{b}}$ & $4.363^{\mathrm{b}}$ & 4.259 \\
\hline & \multirow[t]{3}{*}{$\psi_{\mathrm{Eo}} /\left(1-\psi_{\mathrm{Eo}}\right)$} & $\mathrm{LN}$ & $0.721^{\mathrm{a}}$ & $0.722^{\mathrm{a}}$ & $0.669^{\mathrm{a}}$ & $0.740^{\mathrm{a}}$ & $0.696^{\mathrm{a}}$ \\
\hline & & $\mathrm{SN}$ & $0.938^{\mathrm{b}}$ & $1.022^{\mathrm{c}}$ & $0.964^{\mathrm{b}}$ & $1.097^{\mathrm{b}}$ & $0.984^{b}$ \\
\hline & & $\mathrm{HN}$ & $0.867^{\mathrm{b}}$ & $0.873^{\mathrm{b}}$ & $0.993^{b}$ & $1.193^{\mathrm{c}}$ & $1.037^{\mathrm{b}}$ \\
\hline & \multirow[t]{3}{*}{$\mathrm{PI}_{\mathrm{ABS}}$} & $\mathrm{LN}$ & $1.662^{\mathrm{a}}$ & $1.597^{\mathrm{a}}$ & $1.547^{\mathrm{a}}$ & $1.434^{\mathrm{a}}$ & $1.531^{\mathrm{a}}$ \\
\hline & & $\mathrm{SN}$ & $2.733^{\mathrm{b}}$ & $2.919^{c}$ & $3.004^{b}$ & $2.895^{\mathrm{b}}$ & $2.603^{b}$ \\
\hline & & $\mathrm{HN}$ & $2.317^{\mathrm{b}}$ & $2.198^{\mathrm{b}}$ & $3.052^{\mathrm{b}}$ & $3.235^{\mathrm{b}}$ & $2.950^{\mathrm{b}}$ \\
\hline & \multirow[t]{3}{*}{$\delta_{\mathrm{Ro}} /\left(1-\delta_{\mathrm{Ro}}\right)$} & $\mathrm{LN}$ & $0.780^{\mathrm{b}}$ & $0.570^{\mathrm{a}}$ & 0.577 & $0.652^{\mathrm{b}}$ & 0.646 \\
\hline & & $\mathrm{SN}$ & $0.655^{\mathrm{a}}$ & $0.613^{\mathrm{b}}$ & 0.589 & $0.562^{\mathrm{a}}$ & 0.578 \\
\hline & & $\mathrm{HN}$ & $0.589^{\mathrm{a}}$ & $0.568^{\mathrm{a}}$ & 0.593 & $0.612^{\mathrm{ab}}$ & 0.607 \\
\hline & \multirow[t]{3}{*}{$\mathrm{PI}_{\text {total }}$} & $\mathrm{LN}$ & $1.270^{\mathrm{a}}$ & $0.918^{\mathrm{a}}$ & $0.875^{\mathrm{a}}$ & $0.898^{\mathrm{a}}$ & $0.934^{\mathrm{a}}$ \\
\hline & & $\mathrm{SN}$ & $1.839^{\mathrm{b}}$ & $1.791^{\mathrm{c}}$ & $1.790^{\mathrm{b}}$ & $1.618^{\mathrm{b}}$ & $1.522^{\mathrm{b}}$ \\
\hline & & $\mathrm{HN}$ & $1.436^{\mathrm{a}}$ & $1.258^{\mathrm{b}}$ & $1.812^{\mathrm{b}}$ & $1.945^{\mathrm{c}}$ & $1.806^{\mathrm{b}}$ \\
\hline
\end{tabular}




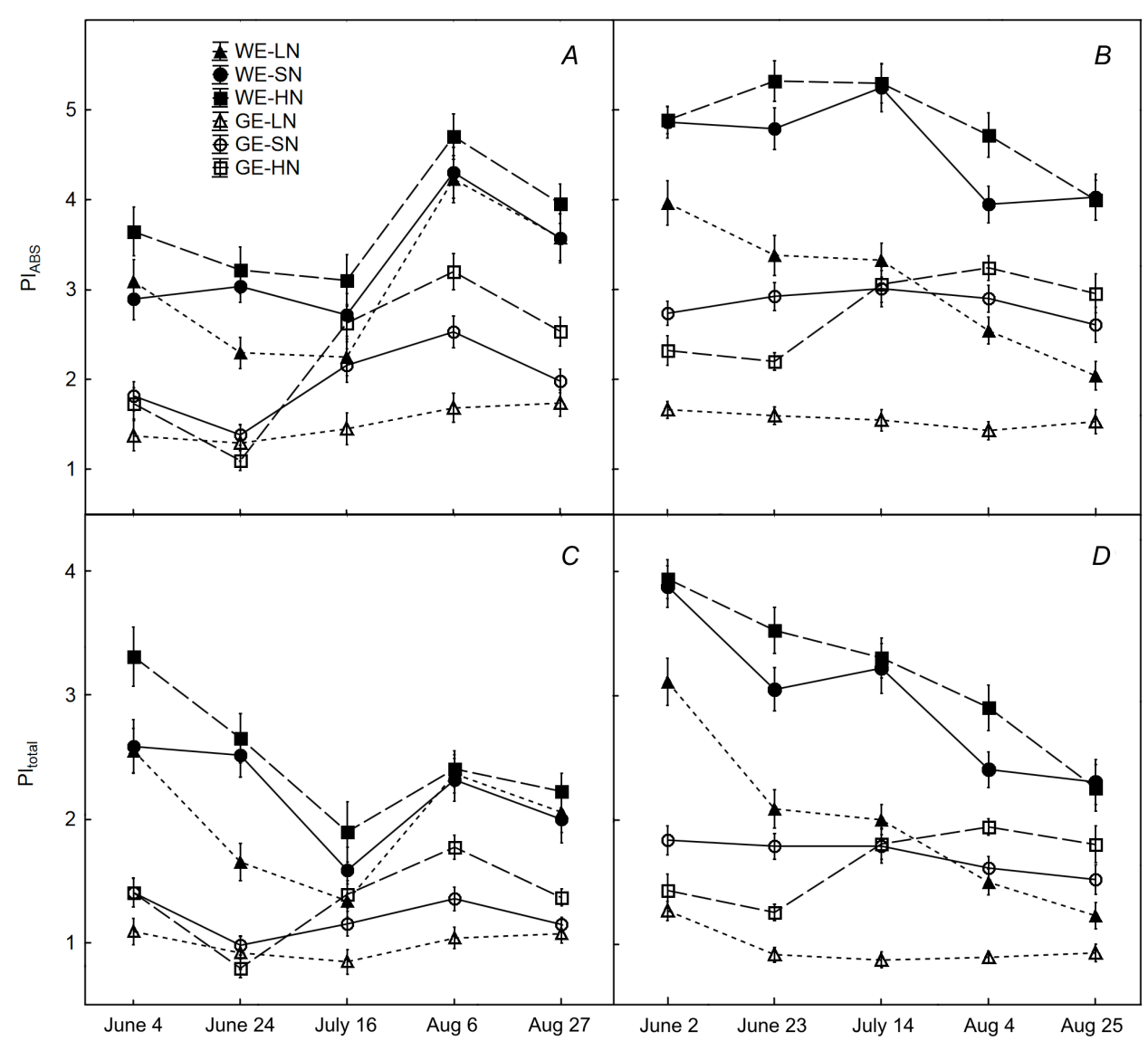

Fig. 4. Performance index $\left(\mathrm{PI}_{\mathrm{ABS}}\right)(A, B)$ and total performance index $\left(\mathrm{PI}_{\text {total }}\right)(C, D)$ during the growing seasons $2015(A, C)$ and 2016 $(B, D)$ in two Actinidia arguta cultivars 'Weiki' (WE) and 'Geneva' (GE). The plants were treated with minimal (LN), standard (SN), and increased $(\mathrm{HN})$ nitrogen supply. Values are means $\pm \mathrm{SE}$.

and of $\mathrm{PI}_{\text {total }}$ in 'Geneva' in the beginning of the growing season (Fig. 4A,C). In 2016, both performance indices showed depletion towards the end of the growing season in 'Weiki' and remained stable to some extent in 'Geneva', however, well N-supported 'Geneva' showed moderate increase (Fig. 4B,D). Both $\mathrm{PI}_{\mathrm{ABS}}$ and $\mathrm{PI}_{\text {total }}$ were dependent also on cultivar traits in each season. Based on the twoway $A N O V A$, we found that in 2015 cultivar traits did not influence the effect of $\mathrm{N}$ nutrition on $\mathrm{PI}_{\mathrm{ABS}}$ and $\mathrm{PI}_{\text {total }}$, but in 2016, they did.

Insufficient $\mathrm{N}$ nutrition significantly affected the total number of reaction centres per absorption ( $\mathrm{RC} / \mathrm{ABS}$ ) and density of RCs per cross section $\left(\mathrm{RC} / \mathrm{CS}_{0}\right)$ on particular measurement days in 2015 and during the whole growing season in 2016 (Tables 1,2). The similar pattern was found in $\mathrm{V}_{\mathrm{K}} / \mathrm{V}_{\mathrm{J}}$ (Tables 1,2$)$.

PCA showed high effect of 'measurement day $\times \mathrm{N}$ treatment' combination on the parameters describing PSII performance (PC1, Fig. $5 A$ ). The parameter $\mathrm{V}_{\mathrm{K}} / \mathrm{V}_{\mathrm{J}}$, describing the efficiency of electron flow from OEC to PSII reaction centres, the density of active reaction centres per PSII antenna chlorophyll (RC/ABS), and the efficiency of total electron transport beyond $\mathrm{Q}_{\mathrm{A}}\left(\psi_{\mathrm{Eo}}\right)$ are located directly along the $x$ axis and nearly parallelly to total $\mathrm{N}$ leaf content. The $\delta_{\mathrm{Ro}} /\left(1-\delta_{\mathrm{Ro}}\right)$ ratio allocation on the $y$ axis suggests the performance of end electron acceptors at PSI as PC2.

The distribution of 'year $\times \mathrm{N}$ treatment' combination showed the influence of $\mathrm{N}$ treatment on energy fluxes around both photosystems, the coordinates of LN samples were distanced from $\mathrm{SN}$ and $\mathrm{HN}$ in both directions in most cases. In 'Geneva', LN coordinates indicate higher $\delta_{\mathrm{Ro}} /\left(1-\delta_{\mathrm{Ro}}\right)$ values, in 'Weiki', LN coordinates indicate lower $\delta_{\mathrm{Ro}} /\left(1-\delta_{\mathrm{Ro}}\right)$ ratio. In both cultivars and both years, the higher $\mathrm{N}$ doses were applied, the higher coordinates of PSII performance parameters were shown in the diagram (Fig. 5B).

\section{Discussion}

Considering the difference in climatic conditions between two experimental growing seasons, some obtained $\mathrm{ChF}$ parameters reflected an influence of insufficient precipitation despite regular irrigation applied on the experimental plantation. The first part of 2015 growing season was extremely dry and a general trend in $\mathrm{F}_{\mathrm{v}} / \mathrm{F}_{\mathrm{m}}, \psi_{\mathrm{Eo}}$, and $\mathrm{PI}_{\mathrm{ABS}}$ in 2015 suggest increased photoinhibition at that time (Figs. $3 A, C ; 4 A$ ). These findings were also shown by Fini et al. (2009), Wang et al. (2012a), and Swoczyna et al. (2015). The 2016 growing season was more abundant 

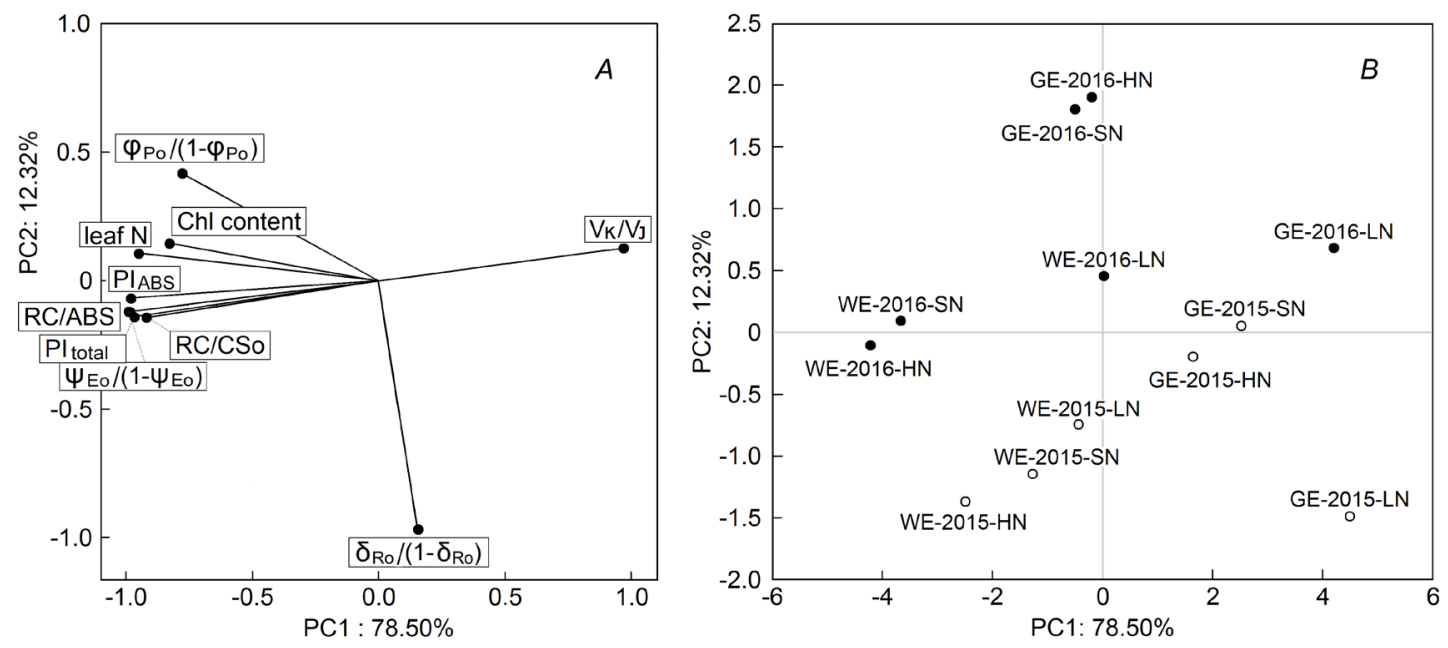

Fig. 5. Principal Component Analysis (PCA) on parameters obtained during 2015 and 2016 for minimum N treatment (LN), standard $\mathrm{N}$ treatment (SN), and increased $\mathrm{N}$ treatment (HN) in Actinidia arguta 'Weiki' (WE) and 'Geneva' (GE). Correlation between variables along two PCA axes $(A)$ and ordination of cases along two PCA axes $(B)$ was based on data from three averaged samples of LN, SN, and $\mathrm{HN}$ from particular measurement days.

in precipitation and the higher $\mathrm{F}_{\mathrm{v}} / \mathrm{F}_{\mathrm{m}}, \psi_{\mathrm{Eo}}$, and $\mathrm{PI}_{\mathrm{ABS}}$ values recorded in 2016 compared to 2015 might be an answer to more favourable growing conditions.

Beside the reaction to climatic conditions, recorded $\mathrm{ChF}$ parameters showed also some differences between two cultivars. Throughout two years of the experiment, 'Weiki' revealed higher values of the parameters describing efficiencies of particular processes connected with energy transfer around PSII, $\mathrm{F}_{\mathrm{v}} / \mathrm{F}_{\mathrm{m}}, \psi_{\mathrm{E}}$, and additionally, $\mathrm{PI}_{\mathrm{ABS}}$, which is the parameter integrating the previous ones. These findings indicate that 'Weiki' has generally a higher potential in solar energy conversion for biochemical processes and confirm better vitality and plasticity of this cultivar.

As diurnal changes may affect $\mathrm{PI}_{\mathrm{ABs}}$ in field conditions (Živčák et al. 2014b), PI total should also be considered. $\mathrm{PI}_{\text {total }}$ was in average also higher in 'Weiki' than that in 'Geneva', although the fourth factor in $\mathrm{PI}_{\text {total }}$ calculation, $\delta_{\mathrm{Ro}} /\left(1-\delta_{\mathrm{Ro}}\right)$ ratio, was higher in 'Geneva'. Both parameters, $\delta_{\mathrm{Ro}}$ and $\delta_{\mathrm{Ro}} /\left(1-\delta_{\mathrm{Ro}}\right)$ ratio, describe electron flow through end electron acceptors (carriers) at PSI (plastocyanin, ferredoxin) but not exactly the PSI (Živčák et al. 2015a). The analysis of $\delta_{\mathrm{Ro}}$ and $\delta_{\mathrm{Ro}} /\left(1-\delta_{\mathrm{Ro}}\right)$ ratio is not very common in environmental research because results are not unambiguous in field experiments (Ugolini et al. 2012). In controlled conditions, while gradual leaf desiccation evoked decrease in $\mathrm{F}_{\mathrm{v}} / \mathrm{F}_{\mathrm{m}}$ (denoted also as $\varphi_{\text {Po }}$ or $\mathrm{TR}_{0} / \mathrm{ABS}$ ), and often in $\psi_{\mathrm{Eo}}$ (denoted also as $\mathrm{ET}_{0} / \mathrm{TR}_{0}$ ), $\delta_{\mathrm{Ro}}$ values were increasing during the first steps of stress and only severe stress caused depletion of the efficiency of electron transport up to end electron acceptors of PSI (Strasser et al. 2010, Goltsev et al. 2012). Shifted $\delta_{\text {Ro }}$ values were found in heat-stressed young leaves compared to heat-stressed mature leaves (Brestič et al. 2012, Duan et al. 2015). Those findings suggest a certain role of end electron acceptors at PSI in recovery of electron transport processes between PSII and PSI. In our experiment, higher
$\delta_{\mathrm{Ro}}$ values, exceeding 0.4 , were recorded on 4 and 24 June, 2015 (dry season), and on 2 June 2016 (moderate season), in both cultivars (data not shown, for statistical differences see $\delta_{\mathrm{Ro}} /\left(1-\delta_{\mathrm{Ro}}\right)$ ratio in Tables 1,2$)$. A minor $\delta_{\mathrm{Ro}}$ increase was found in August 2015 and 2016 in N-deficient 'Geneva' specimens. Therefore, we found higher $\delta_{\text {Ro }}$ values as a symptom of some environmentally evoked imbalance in electron transport between PSII and PSI. Nevertheless, the $\delta_{\mathrm{Ro}} /\left(1-\delta_{\mathrm{Ro}}\right)$ ratio was the least sensitive parameter in our experiment, and it did not show evident differences between cultivars, growing seasons, and in most cases, $\mathrm{N}$ treatments. Similar results were found in tomato plants by Kalaji et al. (2014a). Some researchers combine efficiency of electron transport up to end electron acceptors of PSI, $\delta_{\text {Ro }}$, and the efficiency of a movement of electron into the electron transport chain beyond $\mathrm{Q}_{\mathrm{A}}, \psi_{\mathrm{E}}$. The combined parameter, denoted as $\psi_{\text {REo }}$ or $\Delta \mathrm{V}_{\mathrm{IP}}$, shows total efficiency of electron transport from PSII to PSI (Živčák et al. 2015a). It illustrates the increased pool of reduced $\mathrm{Q}_{\mathrm{A}}^{-}$in plants facing ozone exposure (Desotgiu et al. 2012), salinity or drought stress (Salvatori et al. 2014), and thermal stress connected with drought (Pšidová et al. 2018). In our experiment, $\psi_{\text {REo }}$ was significantly lower in N-deficient plants both in 2015 and 2016, and both cultivars revealed the same pattern (data not shown). This was in contrast with $\delta_{R_{0}}$ results and indicated that plastoquinone pool and/ or cytochrome $b_{6} f$ became the bottle-neck for electron transport in case of nitrogen deficiency.

Taking into account other parameters, the different $\mathrm{N}$ nutrition affected both cultivars, however, not in the same manner. $\mathrm{F}_{\mathrm{v}} / \mathrm{F}_{\mathrm{m}}$ revealed poor reaction to different $\mathrm{N}$ doses in 'Weiki' showing simultaneously higher values in June, compared to 'Geneva' in 2015. Minor or none $F_{v}$ / $\mathrm{F}_{\mathrm{m}}$ reaction to $\mathrm{N}$ deficit was reported by Lu et al. (2001). Maximum quantum efficiency $\left(\mathrm{F}_{\mathrm{v}} / \mathrm{F}_{\mathrm{m}}=\varphi_{\mathrm{Po}_{\mathrm{o}}}\right)$ and its calculated ratio $\varphi_{\mathrm{Po}} /\left(1-\varphi_{\mathrm{PO}_{\mathrm{O}}}\right)$ were reported as susceptible to $\mathrm{N}$ deficit (Kalaji 2011, Živčák et al. 2014a, Feng et al. 
2015). But these parameters are also affected by drought or heat (Kalaji et al. 2011a,b; Wang et al. 2012b). We suppose that the more drought-resistant 'Weiki' revealed higher and more stable $F_{v} / F_{m}$ as a result of acclimation to drought prolonging since May. This was also reflected by $\mathrm{PI}_{\mathrm{ABS}}$ in 'Weiki'. $\mathrm{PI}_{\mathrm{ABS}}$ in 'Geneva' was more affected by different $\mathrm{N}$ nutrition, especially on 6 August, when photosynthetic performance was significantly different between three $\mathrm{N}$ treatments. Here, $\mathrm{PI}_{\mathrm{ABS}}$ was influenced by significantly different RC/ABS and $\psi_{\mathrm{E}}$ values according to different $\mathrm{N}$ treatment. In 2016, low $\mathrm{N}$ doses induced significant decrease in $\mathrm{RC} / \mathrm{ABS}, \mathrm{F}_{\mathrm{v}} / \mathrm{F}_{\mathrm{m}}, \psi_{\mathrm{Eo}}, \mathrm{PI}_{\mathrm{ABS}}$, and $\mathrm{PI}_{\text {total }}$. On particular measurement days, high $\mathrm{N}$ doses resulted in the presence of an additional statistically homogenous group for HN (Table 2). This suggests that 2016 season was more favourable for $\mathrm{N}$ uptake and utilisation by plants. Favourable water conditions were previously reported to be crucial for $\mathrm{N}$ uptake (Bai et al. 2017), and for an increase of the efficiency of $\mathrm{N}$ utilisation in photosynthesising tissues (Teixeira et al. 2014).

In 2015, the most sensitive parameter to $\mathrm{N}$ nutrition was density of active RCs per cross section $\left(\mathrm{RC} / \mathrm{CS}_{0}\right)$. In 'Weiki', it was the only parameter which showed the effectiveness of increased $\mathrm{N}$ nutrition at most measurement days. In 'Geneva', the increased number of active RCs per cross section was additionally reflected by higher $\mathrm{RC} /$ ABS. This suggests that both 'Weiki' and 'Geneva' tend to activate a higher number of RCs while better supported with $\mathrm{N}$ nutrition. It is well known that higher $\mathrm{N}$ content results in higher Chl concentration in leaves (Loh et al. 2002, Chang and Robison 2003), but it is also important to conclude that better $\mathrm{N}$ supplementation was proven to increase a number of reaction centres in photosystems and to better utilise the energy harvested by chloroplast antennas. The results from moderate 2016 season show that standard $\mathrm{N}$ nutrition accompanied by proper water availability supports the optimal number of Chl molecules needed for the RCs in photosystems. The similar patterns of both $\mathrm{RC} / \mathrm{CS}_{0}$ and $\mathrm{RC} / \mathrm{ABS}$ statistics (Table 2) suggest that these parameters are good indicators for $\mathrm{N}$ deficiency which was also demonstrated by Kalaji (2011) and Redillas et al. (2011). Moreover, regardless of climatic conditions, in most cases $\mathrm{RC} / \mathrm{CS}_{0}$ did not exceed values of 360 and 400 in 'Geneva' and 'Weiki', respectively. This indicates that $\mathrm{RC} / \mathrm{CS}_{0}$ is directly dependent on $\mathrm{N}$ supplementation and it is possible to define a threshold specific for particular species/cultivars.

In the early season 2015, the effect of $\mathrm{N}$ supplementation on the efficiency of total electron transport beyond $\mathrm{Q}_{\mathrm{A}}$ $\left(\psi_{\mathrm{Eo}}\right)$ was not clearly visible (in 'Weiki', only the highest $\mathrm{N}$ supply caused the statistically higher $\psi_{\mathrm{Eo}}$ ) and this might be a result of limited water availability in June (Fig. 3C,D). In July and August 2015, more sensitive 'Geneva' showed high dependence on $\mathrm{N}$ nutrition. Thus, we can suppose that different reactions to $\mathrm{N}$ supply in dry year indicate different characteristics of the examined cultivars based probably on their provenance (Pšidová et al. 2018). 'Geneva' seems to be more sensitive to drought and poor nitrogen availability, 'Weiki' seems to show more continental-like traits. In 2016, both cultivars revealed higher sensibility of $\psi_{\mathrm{E} o}$ depending on $\mathrm{N}$ supply. Moreover, not only the standard doses but also the highest doses of $\mathrm{N}$ increased significantly $\psi_{\text {Eo }}$ on particular measurement days in 2015 and 2016. This indicates that electron movement in ETC beyond $\mathrm{Q}_{\mathrm{A}}$ is visibly dependent on $\mathrm{N}$ availability which was also confirmed by Lu et al. (2001), Lin et al. (2013), and Kalaji et al. (2014a), as well as by differences between $\psi_{\text {REo }}$ and $\delta_{\text {Ro }}$ discussed above. $N$ is not only a component of $\mathrm{Chl}$ molecules but also of proteins involved in numerous biochemical processes and of electron, proton, and energy carriers (NADPH, ATP). Thus, the different $\mathrm{N}$ supply in Actinidia may affect also the efficiency of total electron transport beyond $\mathrm{Q}_{\mathrm{A}}\left(\psi_{\mathrm{Eo}}\right)$, i.e. the PSII acceptor side, and the based-on-it calculated parameter $\psi_{\mathrm{Eo}} /\left(1-\psi_{\mathrm{Eo}}\right)$ which is the component of two performance indices. These results were also confirmed by Kalaji (2011).

Discussing $\mathrm{ChF}$ parameters describing consecutive processes of light energy conversion it is worthy to analyse the effect of $\mathrm{N}$ supplementation on PSII donor side. In previous research, it was noticed that heat or drought stress conditions may evoke an additional shift in fast fluorescence records, so called K-step (Strasser et al. 2004, Oukarroum et al. 2007), which is related to an inactivation or disconnection of water-splitting complex. Schmitz et al. (2001) showed that the higher $\mathrm{N}$ deficit was set to Vigna uncuiculata plants, the more visible fluorescence increase appeared at $\mathrm{K}$ point. Likewise, Redillas et al. (2011) reported the formation of $\mathrm{K}$-band in $\mathrm{N}$-deficient rise seedlings. On the contrary, additional $\mathrm{N}$ supplementation may diminish the ratio $V_{K} / V_{J}$ in plants growing in field top soil (Li et al. 2012). In our research, $\mathrm{V}_{\mathrm{K}} / \mathrm{V}_{\mathrm{J}}$ revealed a significant shift in $\mathrm{N}$-deficient plants in both cultivars in moderate season 2016. This suggests the important role of $\mathrm{N}$ in the processes connected with oxygen evolving and electron donation to RCs of PSII. In water-deficient season 2015, $\mathrm{V}_{\mathrm{K}} / \mathrm{V}_{\mathrm{J}}$ ratio increased in N-deficient 'Geneva' and incidentally in N-deficient 'Weiki'.

In order to summarise which components of $\mathrm{PI}_{\mathrm{ABS}}$ and $\mathrm{PI}_{\text {total }}$ equations are the most dependent on $\mathrm{N}$ nutrition, the principal component analysis was performed. PCA showed higher effect of 'climate-conditions $\times \mathrm{N}$ treatment' combination on the parameters describing PSII performance (PC1, Fig. 5A). The density of active RCs per PSII antenna Chl (RC/ABS) and efficiency of electron movement by trapped exciton into the electron transport chain beyond the $\mathrm{Q}_{\mathrm{A}}\left[\psi_{\mathrm{Eo}} /\left(1-\psi_{\mathrm{Eo}}\right)\right]$ along with $\mathrm{V}_{\mathrm{K}} / \mathrm{V}_{\mathrm{J}}$, describing the efficiency of electron flow from OEC to PSII reaction centres, and $\mathrm{RC} / \mathrm{CS}_{0}$, are located directly along the $x$ axis and almost parallel to total $\mathrm{N}$ leaf content. These parameters seem to be directly conditioned by $\mathrm{N}$ availability for plants. The probability that the absorbed photon will be trapped by $\mathrm{RC}$, expressed as $\varphi_{\mathrm{Po}} /\left(1-\varphi_{\mathrm{Po}}\right)$, is also affected by $\mathrm{N}$ nutrition to a certain extent, but beside PSII structure other factors may determine the maximum quantum efficiency of PSII. De Castro et al. (2014) found that $\varphi_{\mathrm{Po}_{\mathrm{o}}}\left(\mathrm{F}_{\mathrm{v}} / \mathrm{F}_{\mathrm{m}}\right)$ was affected by $\mathrm{Chl}$ content only when $\mathrm{Chl}$ was lacking. The $\delta_{\mathrm{Ro}} /\left(1-\delta_{\mathrm{Ro}}\right)$ ratio allocation on the $y$ axis suggests the lower dependence of the performance of end electron acceptors around PSI (PC2 $=12.32 \%$, Fig. $5 A$ ) upon $\mathrm{N}$ content. 
Ordination of cases along two PCA axes showed different characteristics of two examined cultivars. 'Geneva' appeared more susceptible both to climatic conditions and N deficiency. GE-2015 and GE-2016 clusters are more separated from each other than WE-2015 and WE-2016 clusters. In both years low N nutrition affected visibly the performance of PSII in 'Geneva'. High N nutrition amended it to some extent in dry season 2015, but had no effect in 2016. Furthermore, in 'Geneva', the efficiency of end electron acceptors at PSI positively supported PSII performance in plants treated with low $\mathrm{N}$ supply in both years. Conversely, in 'Weiki', the efficiency of end electron acceptors at PSI was not much affected by $\mathrm{N}$ nutrition. Climatic conditions had no influence here, as well. Considering the performance of PSII, the N nutrition in 'Weiki' was effective only in the growing season with sufficient precipitation, in former drier season, the effect was less visible. These findings show that 'Weiki' is not only able to cope better with scarce water availability but also reveals higher independence from $\mathrm{N}$ availability when affected by drought conditions. The differences in nitrogen-use efficiency between different cultivars were found also in winter wheat (Fan and Li 2001).

Conclusions: Two examined cultivars differ in the efficiency of light energy conversion when facing nitrogen deficiency. The highest differences were found in the efficiency of electron transport chain performance indicating ecophysiological differences between both cultivars. Chlorophyll $a$ fluorescence measurements in the field experiment allowed us to evaluate usefulness of the ChF parameters in detecting $\mathrm{N}$ deficiency. In field conditions, several factors may determinate plant vitality. The integrating ChF parameters, $\mathrm{PI}_{\mathrm{ABS}}$ and $\mathrm{PI}_{\text {total }}$, are useful to detect the overall decrease in plant performance. They are very sensible, but cannot indicate a factor responsible for negative changes. Considering all components of $\mathrm{PI}_{\mathrm{ABS}}$ and $\mathrm{PI}_{\text {total }}$ calculations, in our experiment, $\psi_{\mathrm{Eo}} /\left(1-\psi_{\mathrm{Eo}}\right)$ was more susceptible to different $\mathrm{N}$ nutrition and $\mathrm{RC} / \mathrm{ABS}$ was the best indicator. Beside the above mentioned parameters, we recommend to analyse the $\mathrm{RC} / \mathrm{CS}_{0}$, which is strictly connected with $\mathrm{N}$ availability for chlorophyll synthesis. We found that regardless of the climatic conditions, the $\mathrm{RC} / \mathrm{CS}_{0}$ values beneath experimentally defined thresholds may indicate insufficient $\mathrm{N}$ supply.

\section{References}

Allakhverdiev S.I., Kreslavski V.D., Klimov V.V. et al.: Heat stress: an overview of molecular responses in photosynthesis. - Photosynth. Res. 98: 541-550, 2008.

Ashraf M., Shahbaz M., Ali Q.: Drought-induced modulation in growth and mineral nutrients of canola (Brassica napus L.). Pak. J. Bot. 45: 93-98, 2013.

Baccarin M.A., Deuner S., da Silva F.S.P. et al.: Chlorophyll $a$ fluorescence as indicative of the salt stress on Brassica napus L. - Braz. J. Plant Physiol. 23: 245-253, 2011.

Bai J., Jia J., Huang C. et al.: Selective uptake of nitrogen by Suaeda salsa under drought and salt stresses and nitrogen fertilization using ${ }^{15}$ N. - Ecol. Eng. 102: 542-545, 2017.

Brestič M., Živčák M.: PSII fluorescence techniques for measurement of drought and high temperature stress signal in crop plants: protocols and applications. - In: Rout G.R., Das A.B. (ed.): Molecular Stress Physiology of Plants. Pp. 87-131. Springer, Dordrecht 2013.

Brestič M., Živčák M., Kalaji H.M. et al.: Photosystem II thermostability in situ: Environmentally induced acclimation and genotype-specific reactions in Triticum aestivum L. Plant Physiol. Bioch. 57: 93-105, 2012.

Brestič M., Živčák M., Kunderlíková K., Allakhverdiev S.I.: High temperature specifically affects the photoprotective responses of chlorophyll $b$-deficient wheat mutant lines. Photosynth. Res. 130: 251-266, 2016.

Bussotti F., Desotgiu R., Pollastrini M., Cascio C.: The JIP test: a tool to screen the capacity of plant adaptation to climate change. - Scand. J. Forest Res. 25: 43-50, 2010.

Chang S.X., Robison D.J.: Nondestructive and rapid estimation of hardwood foliar nitrogen status using the SPAD-502 chlorophyll meter. - Forest Ecol. Manag. 181: 331-338, 2003.

Christen D., Schönmann S., Jermini M. et al.: Characterization and early detection of grapevine (Vitis vinifera) stress responses to esca disease by in situ chlorophyll fluorescence and comparison with drought stress. - Environ. Exp. Bot. 60: 504-514, 2007.

da Silva T.R., Cazetta J.O., Carlin S.D., Telles B.R.: Droughtinduced alterations in the uptake of nitrogen, phosphorus and potassium, and the relation with drought tolerance in sugar cane. - Ciência e Agrotecnologia 41: 117-127, 2017.

De Castro F.A., Campostrini E., Torres Netto A. et al.: Portable chlorophyll meter (PCM-502) values are related to total chlorophyll concentration and photosynthetic capacity in papaya (Carica papaya L.). - Theor. Exp. Plant Phys. 26: 201-210, 2014.

Desotgiu R., Pollastrini M., Cascio C. et al.: Chlorophyll a fluorescence analysis along a vertical gradient of the crown in a poplar (Oxford clone) subjected to ozone and water stress. Tree Physiol. 32: 976-986, 2012.

Dordas C, Sioulas C.: Safflower yield, chlorophyll content, photosynthesis, and water use efficiency response to nitrogen fertilization under rainfed conditions. - Ind. Crop. Prod. 27: 75-85, 2008

Duan Y., Zhang M., Gao J. et al.: Thermotolerance of apple tree leaves probed by chlorophyll $a$ fluorescence and modulated $820 \mathrm{~nm}$ reflection during seasonal shift. - J. Photoch. Photobio. B 152: 347-356, 2015.

Fan X.L., Li Y.K.: Effect of drought stress and drought tolerance heredity on nitrogen efficiency of winter wheat. - In: Horst W.J., Schenk M.K., Bürkert A. et al. (ed.): Plant nutrition Food Security and Sustainability of Agro-Ecosystems. Pp. 6263. Springer, Dordrecht 2001.

Feng W., He L., Zhang H. et al.: Assessment of plant nitrogen status using chlorophyll fluorescence parameters of the upper leaves in winter wheat. - Eur. J. Agron. 64: 78-87, 2015.

Fini A., Ferrini F., Frangi P. et al.: Withholding irrigation during the establishment phase affected growth and physiology of Norway maple (Acer platanoides) and linden (Tilia spp.). Arboricult. Urban Forest. 35: 241-251, 2009.

Goltsev V., Zaharieva I., Chernev P. et al.: Drought-induced modifications of photosynthetic electron transport in intact leaves: Analysis and use of neural networks as a tool for a rapid non-invasive estimation. - BBA- Bioenergetics 1817: 1490-1498, 2012.

Guha A., Sengupta D., Reddy A.R.: Polyphasic chlorophyll $a$ fluorescence kinetics and leaf protein analyses to track dynamics of photosynthetic performance in mulberry during progressive drought. - J. Photoch. Photobio. B: 119: 71-83, 2013. 
Guo Y.Y., Yu H.Y., Kong D.S. et al.: Effects of drought stress on growth and chlorophyll fluorescence of Lycium ruthenicum Murr. seedlings. - Photosynthetica 54: 524-531, 2016.

Gururani M.A., Upadhyaya C.P., Baskar V. et al.: Plant growthpromoting Rhizobacteria enhance abiotic stress tolerance in Solanum tuberosum through inducing changes in the expression of ROS-scavenging enzymes and improved photosynthetic performance. - J. Plant Growth Regul. 32: 245-258, 2013.

$\mathrm{Hu}$ Y., Schmidhalter U.: Drought and salinity: a comparison of their effects on the mineral nutrition of plants. - J. Plant Nutr. Soil Sci. 168: 541-549, 2005.

Janušauskaite D., Feiziene D.: Chlorophyll fluorescence characteristics throughout spring triticale development stages as affected by fertilization. - Acta Agr. Scand. B-S. P. 62: $7-15,2012$

Kalaji M.H.: [Influence of abiotic stress factors on chlorophyll fluorescence in selected varieties of barley Hordeum vulgare L. plants]. Pp. 176. Wydawnictwo SGGW, Warszawa 2011. [In Polish]

Kalaji H.M., Bosa K., Kościelniak J., Hossain Z.: Chlorophyll a Fluorescence - A Useful Tool for the Early Detection of Temperature Stress in Spring Barley (Hordeum vulgare L.). Omics 15: 925-934, 2011a.

Kalaji H.M., Govindjee, Bosa K. et al.: Effects of salt stress on photosystem II efficiency and $\mathrm{CO}_{2}$ assimilation of two Syrian barley landraces. - Environ. Exp. Bot. 73: 64-72, 2011b.

Kalaji H.M., Oukarroum A., Alexandrov V. et al.: Identification of nutrient deficiency in maize and tomato plants by in vivo chlorophyll $a$ fluorescence measurements. - Plant Physiol. Bioch. 81: 16-25, 2014a.

Kalaji H.M., Račková L., Paganová V. et al.: Can chlorophyll- $a$ fluorescence parameters be used as bio-indicators to distinguish between drought and salinity stress in Tilia cordata Mill? - Environ. Exp. Bot. 152: 149-157, 2018.

Kalaji H.M., Schansker G., Ladle R.J. et al.: Frequently asked questions about in vivo chlorophyll fluorescence: practical issues. - Photosynth. Res. 122: 121-158, $2014 b$.

Latocha P.: The nutritional and health benefits of kiwiberry (Actinidia arguta) - a review. - Plant Food. Hum. Nutr. 72: 325-334, 2017.

Leontowicz M., Leontowicz H., Jesion I. et al.: Actinidia arguta supplementation protects aorta and liver in rats with induced hypercholesterolemia. - Nutr. Res. 36: 1231-1242, 2016.

Li G., Zhang Z.-S., Gao H.-Y. et al.: Effects of nitrogen on photosynthetic characteristics of leaves from two different stay-green corn (Zea mays L.) varieties at the grain-filling stage. - Can. J. Plant Sci. 92: 671-680, 2012.

Lin Y.C., Hu Y.G., Ren C.Z. et al.: Effects of nitrogen application on chlorophyll fluorescence parameters and leaf gas exchange in naked oat. - J. Integr. Agr. 12: 2164-2171, 2013.

Loh F.C.W., Grabosky J.C., Bassuk N.L.: Using the SPAD 502 meter to assess chlorophyll and nitrogen content of benjamin fig and cottonwood leaves. - HortTechnology 12: 682-686, 2002.

Lu C., Zhang J., Zhang C. et al.: Modification of photosystem II photochemistry in nitrogen deficient maize and wheat plants. - J. Plant Physiol. 158: 1423-1430, 2001.

Makino A.: Rubisco and nitrogen relationships in rice: Leaf photosynthesis and plant growth. - Soil Sci. Plant Nutr. 49: 317-327, 2003.

Mathur S., Jajoo A.: Alterations in photochemical efficiency of photosystem II in wheat plant on hot summer day. - Physiol. Mol. Biol. Pla. 20: 527-531, 2014.

Mehta P., Allakhverdiev S.I., Jajoo A.: Characterization of photosystem II heterogeneity in response to high salt stress in wheat leaves (Triticum aestivum). - Photosynth. Res. 105: 249-255, 2010.

Oukarroum A., El Madidi S., Schansker G., Strasser R.J.: Probing the responses of barley cultivars (Hordeum vulgare L.) by chlorophyll $a$ fluorescence OLKJIP under drought stress and re-watering. - Environ. Exp. Bot. 60: 438-446, 2007.

Percival G.C., Keary I.P., Al-Habsi S.: An assessment of the drought tolerance of Fraxinus genotypes for urban landscape plantings. - Urban For. Urban Gree. 5: 17-27, 2006.

Porcar-Castell A., Tyystjärvi E., Atherton J. et al.: Linking chlorophyll $a$ fluorescence to photosynthesis for remote sensing applications: mechanisms and challenges. - J. Exp. Bot. 65: 4065-4095, 2014.

Pšidová E., Živčák M., Stojnić S. et al.: Altitude of origin influences the responses of PSII photochemistry to heat waves in European beech (Fagus sylvatica L.). - Environ. Exp. Bot. 152: 97-106, 2018.

Puri G., Ashman M.R.: Relationship between soil microbial biomass and gross $\mathrm{N}$ mineralisation. - Soil Biol. Biochem. 30: 251-256, 1998.

Redillas M.C.F.R., Jeong J.S., Strasser R.J. et al.: JIP analysis on rice (Oryza sativa cv Nipponbare) grown under limited nitrogen conditions. - J. Korean Soc. Appl. Bi. 54: 827-832, 2011.

Salvatori E., Fusaro L., Gottardini E. et al.: Plant stress analysis: Application of prompt, delayed chlorophyll fluorescence and $820 \mathrm{~nm}$ modulated reflectance. Insights from independent experiments. - Plant Physiol. Bioch. 85: 105-113, 2014.

Schmitz P., Maldonado-Rodriguez R., Strasser R.J.: Evaluation of the nodulated status of Vigna unguiculata probed by the JIP-test based on the chlorophyll a fluorescence rise. - In: CSIRO PS 2001 Proceedings: $12^{\text {th }}$ International Congress on Photosynthesis, Vol. 3, No 1. CSIRO Publishing, Melbourne 2001.

Strasser R.J., Govindjee: On the O-J-I-P fluorescence transient in leaves and $\mathrm{Dl}$ mutants of Chlamydomonas reinhardtii. - In: Murata N. (ed.): Research in Photosynthesis. Vol. 4. Pp. 2932. Kluwer Academic Publishers, Dordrecht 1992.

Strasser R.J., Srivastava A., Tsimilli-Michael M.: The fluorescence transient as a tool to characterize and screen photosynthetic samples. - In: Yunus M., Pathre U., Mohanty P. (ed.): Probing Photosynthesis: Mechanism, Regulation and Adaptation. Pp. 443-480. Taylor and Francis, London 2000.

Strasser R.J., Tsimilli-Michael M., Qiang S., Goltsev V.: Simultaneous in vivo recording of prompt and delayed fluorescence and 820-nm reflection changes during drying and after rehydration of the resurrection plant Haberlea rhodopensis. - BBA-Bioenergetics 1797: 1313-1326, 2010.

Strasser R.J., Tsimilli-Michael M., Srivastava A.: Analysis of the chlorophyll $a$ fluorescence transient. - In: Papageorgiou G.C., Govindjee (ed.): Chlorophyll $a$ Fluorescence: A Signature of Photosynthesis. Advances in Photosynthesis and Respiration. Pp. 321-362. Springer, Dordrecht 2004.

Sukhova E., Mudrilov M., Vodeneev V., Sukhov V.: Influence of the variation potential on photosynthetic flows of light energy and electrons in pea. - Photosynth. Res. 136: 215-228, 2018.

Swoczyna T., Kalaji H.M., Pietkiewicz S. et al.: Photosynthetic apparatus efficiency of eight tree taxa as an indicator of their tolerance to urban environments. - Dendrobiology 63: 65-75, 2010.

Swoczyna T., Kalaji H.M., Pietkiewicz S., Borowski J.: Ability of various tree species to acclimation in urban environments probed with the JIP-test. - Urban For. Urban Gree. 14: 544$553,2015$.

Teixeira E.I., George M., Herreman T. et al.: The impact of water and nitrogen limitation on maize biomass and resource-use 
efficiencies for radiation, water and nitrogen. - Field Crop. Res. 168: 109-118, 2014.

Ugolini F., Bussotti F., Lanini G.M. et al.: Leaf gas exchanges and photosystem efficiency of the holm oak in urban green areas of Florence, Italy. - Urban For. Urban Gree. 11: 313$319,2012$.

van den Berg A.K., Perkins T.D.: Evaluation of a portable chlorophyll meter to estimate chlorophyll and nitrogen contents in sugar maple (Acer saccharum Marsh.) leaves. Forest Ecol. Manag. 200: 113-117, 2004.

Wang M., Shi S., Lin F. et al.: Effects of soil water and nitrogen on growth and photosynthetic response of Manchurian ash (Fraxinus mandshurica) seedlings in northeastern China. PLoS ONE 7: e30754, 2012a.

Wang Z.X., Chen L., Ai J. et al.: Photosynthesis and activity of photosystem II in response to drought stress in Amur Grape (Vitis amurensis Rupr.). - Photosynthetica 50: 189-196, 2012b.

Yong J.W.H., Ng Y.F., Tan S.N., Chew A.Y.L.: Effect of fertilizer application on photosynthesis and oil yield of Jatropha curcas L. - Photosynthetica 48: 208-218, 2010.

Yusuf M.A., Kumar D., Rajwanshi R. et al:: Overexpression of $\gamma$-tocopherol methyl transferase gene in transgenic
Brassica juncea plants alleviates abiotic stress: Physiological and chlorophyll $a$ fluorescence measurements. - BBABioenergetics 1797: 1428-1438, 2010.

Živčák M., Brestič M., Kunderlíková K. et al.: Effect of photosystem I inactivation on chlorophyll $a$ fluorescence induction in wheat leaves: does activity of photosystem I play any role in OJIP rise? - J. Photoch. Photobio. B 152: 318-324, $2015 \mathrm{a}$.

Živčák M., Brestič M., Kunderlíková K. et al.: Repetitive light pulse-induced photoinhibition of photosystem I severely affects $\mathrm{CO}_{2}$ assimilation and photoprotection in wheat leaves. - Photosynth. Res. 126: 449-463, 2015 b.

Živčák M., Brestič M., Olšovská K., Slamka P.: Performance index as a sensitive indicator of water stress in Triticum aestivum L. - Plant Soil Environ. 54: 133-139, 2008.

Živčák M., Olšovská K., Slamka P. et al.: Application of chlorophyll fluorescence performance indices to assess the wheat photosynthetic functions influenced by nitrogen deficiency. - Plant Soil Environ. 60: 210-215, 2014a.

Živčák M., Olšovská K., Slamka P. et al: Measurements of chlorophyll fluorescence in different leaf positions may detect nitrogen deficiency in wheat. - Zemdirbyste 101: 437-444, 2014b.

(C) The authors. This is an open access article distributed under the terms of the Creative Commons BY-NC-ND Licence. 